\title{
COVID-19 Tanı Testleri, Tedavisindeki Aşılar ve İlaçlar; Güncel Durum
}

\author{
Derya Selcen SALMANOĞLU ${ }^{1}$, Emine Esin ÇALIŞKAN ${ }^{2}$, Meliz SOFU $^{3}$, \\ Yiğit UYANIKGiL ${ }^{3,4,5}$, Emel Öykü ÇETIN UYANIKGIL ${ }^{2}$
}

1 Ege Üniversitesi Fen Bilimleri Enstitüsü, Biyomedikal Teknolojiler Anabilim Dalı, İzmir.

2 Ege Üniversitesi Eczacıllk Fakültesi, Farmasotik Teknoloji Anabilim Dalı, Biyofarmasotik ve Farmakokinetik Bilim Dalı, İzmir.

3 Ege Üniversitesi Sağlık Bilimleri Enstitüsü, Kök Hücre Anabilim Dalı, İzmir.

4 Ege Üniversitesi Tıp Fakültesi, Histoloji ve Embriyoloji Anabilim Dalı, İzmir.

5 Ege Üniversitesi Kordon Kanı, Hücre-Doku Araştırma ve Uygulama Merkezi, İzmir.

\section{ÖZET}

COVID-19 (Koronavirüs Hastalığı 19) olarak adlandırılan SARS-CoV-2 (Şiddetli akut solunum yolu sendromu koronavirüs-2) virüsünün neden olduğu enfeksiyon başlangıçta Aralık 2019'da Çin'de tespit edilmiștir ve daha sonra dünyaya hızla yayılmıștır. 13 Ocak 2020 tarihinde Tayland Halk Sağlığı Bakanlığı Çin'in Wuhan şehrinde yaşayan 8 Ocak 2020 tarihinde Tayland'a giden 61 yaşında Çinli bir kadında ilk importe olguyu bildirmiştir. Daha sonra 11 Mart'ta Dünya Sağlık Örgütü (DSÖ) bu salgını küresel bir pandemi ilan etmiştir. Hastalı̆̆ın yayılmasını önlemek ve pandemiyi kontrol etmek için ilaçların etkinliği araştırılmakta olup çok sayıda COVID-19 aşı adayı ve ilaç adayı geliştirilmektedir. ABD- Gıda ve İlaç İdaresi (FDA), Aralık 2020'de sırasıyla Pfizer ve Moderna tarafından geliştirilen iki mRNA aşısı için acil kullanım onayı yayınlamıştır. Şu anda geliştirilmekte olan diğer COVID-19 aşıları mRNA, DNA, viral vektör, subünite, inaktive edilmiş ve canlı zayıflatılmış aşıları kapsayan çeşitli platformlara dayanmaktadır. Bu derlemede COVID-19 tanı ve/veya tedavisinde kullanılan testler, aşılar ve ilaçların rolünü incelenmektedir.

Anahtar Kelimeler: Koronavirüs. SARS-CoV-2. İlaç. Aşı. Test.

COVID-19 Diagnostic Tests, Vaccines and Medicines in Its Treatment; Current status

\begin{abstract}
The infection caused by the SARS-CoV-2 (Severe acute respiratory syndrome coronavirus-2) virus, called COVID-19 (Coronavirus disease 19), was initially detected in China in December 2019, and then spread rapidly around the world. On January 13, 2020, the Ministry of Public Health of Thailand reported the first imported case in a 61-year-old Chinese woman living in Wuhan, China, who went to Thailand on January 8, 2020. Later, on March 11, the World Health Organization (WHO) declared this outbreak a global pandemic. The effectiveness of drugs is being investigated to prevent the spread of the disease and control the pandemic, and many COVID-19 vaccine candidates and drug candidates are being developed. The U.S. Food and Drug Administration (FDA) issued emergency-use approval for two mRNA vaccines developed by Pfizer and Moderna, respectively, in December 2020. Other COVID-19 vaccines currently in development are based on a variety of platforms including mRNA, DNA, viral vector, subunit, inactivated and live attenuated vaccines. This review examines the role of tests, vaccines and drugs used in the diagnosis and/or treatment of COVID-19.
\end{abstract}

Key Words: Coronavirus. SARS-CoV-2. Drug. Vaccine. Test.

Geliş Tarihi: 24. Haziran.2021

Kabul Tarihi: 03.Ağustos.2021

Dr. Emel Öykü ÇETIN UYANIKGIL

Ege Üniversitesi Eczacılık Fakültesi,

Farmasotik Teknoloji Anabilim Dalı,

Biyofarmasotik ve Farmakokinetik Bilim Dalı,

İzmir.

Tel.: +90 2323113951

E-posta: emeloykucetin@ege.edu.tr
Yazarların ORCID ID Bilgisi:

Derya Selcen SALMANOGLU: 0000-0001-7435-1725

Emine Esin ÇALIŞKAN: 0000-0002-8837-1222

Meliz SOFU: 0000-0001-6106-2203

Yiğit UYANIKGIL: 0000-0002-4016-0522

Emel Öykü ÇETIN UYANIKGIL: 0000-0001-8822-9130 
İnsan koronavirüsleri (CoVs) ilk olarak 1960'ların sonlarında keşfedilmiştir ${ }^{1}$. Karakteristik taç benzeri görünümü nedeniyle Korona olarak adlandırılmaktadırlar. Koronavirüsler, insanlar ve hayvanları enfekte eden Coronaviridae familyasının, Orthocoronavirinae alt familyası içinde yer alan tek iplikli, pozitif polariteli RNA virüslerdir. Bu virüsler, alfacoronavirus $(\alpha)$, betacoronavirus $(\beta)$, gammacoronavirus $(\gamma)$, ve deltacoronavirus $(\delta)$ olmak üzere 4 major cins ile siniflandırılmaktadırlar. Şu ana kadar, 7 insan koronavirüsü tanımlanmıştır. Bunlar: $\alpha$ türü olan $\mathrm{HCoV} 229 \mathrm{E}$, $\mathrm{HCoV} \mathrm{NL63}$ ve $\beta$ türüne ait olan $\mathrm{HCoV}-\mathrm{OC} 43$, HCoVHKU1, SARS-CoV, MERS-CoV ve SARSCoV-2 koronavirüsleridir ${ }^{2,3}$.

Insan koronavirüsleri hem hafif (OC43, HKU1, 229E ve NL63) hem de şiddetli (SARS-CoV-1, SARS-CoV-2 ve MERS) hastalığa neden olabilirler. Taksonomik olarak SARS-CoV-2, Sarbecovirus alt cinsine ait SARS-ilişkili koronavirüs türlerinin bir parçasıdır.

Koronavirüsler esas olarak epitel hücrelerini hedef alırlar. Koronavirüs türüne bağlı olarak, aerosol, fomit veya fekal-oral yolla bir konakçıdan başka bir konakçıya bulaşmaktadır. İnsan koronavirüsleri solunum yollarının epitel hücrelerini enfekte ederken, hayvan koronavirüsleri genellikle sindirim sisteminin epitel hücrelerini enfekte etmektedir ${ }^{4}$.

Sadece 21. yüzyılın ilk yirmi yılında, insan koronavirüslerinin neden olduğu Şiddetli akut solunum yolu sendromu koronavirüs-1 (SARS-CoV1), Ortadoğu Solunum Yolu Sendromu koronavirüs (MERS-CoV) ve şimdi, yeni bir koronavirüs olan Şiddetli Akut Solunum Yolu Sendromu koronavirüs-2 (SARS-CoV2 veya nCoV-19) olmak üzere üç pandemik bulaşıcı hastalık ortaya çıkmıştır.

Atipik pnömoni (SARS) ilk olarak 2002 yılının sonlarında Çin'in Guangdong eyaletinden bildirilmiştir ${ }^{5}$. Hem SARS-CoV hem de MERS-CoV hayvanlardan insanlara bulaşan zoonotik virüslerdir. Bunlar yarasaları doğal rezervuarları olarak kullanırlar ve yarasalardan ara konakçılara (örneğin, SARS-CoV için misk kedileri, MERS-CoV için develer) iletirler ve insanlarda enfeksiyona yol açarlar ${ }^{6}$.

SARS-CoV-2 diğer koronavirüsler gibi, çoklu yapısal ve yapisal olmayan proteinleri kodlayan $\sim 30$ kilobazlik bir genom boyutuna sahiptir. Bu ve diğer ortaya çıkan patojenik insan Cov'lerinin genomu, dört ana protein olan spike (S) proteini, zarf (E) proteini, membran (M) proteini ve nükleokapsid (N) proteini ile yaklaşık 16 yapısal olmayan proteini (nsp1-16) ve beș ila sekiz yardımcı proteini kodlar. Bunlar arasında, büyük multi fonksiyonel transmembran proteini olan $\mathrm{S}$ glikoproteini; viral bağlanma, füzyon, konakçı hücreye giriş ve iletimde önemli bir rol oynar. S proteini, farklı fonksiyonel domainlere ayrilan S1 ve S2 subünitlerden oluşur.S1 alt birimi, N-terminal domaini (NTD), reseptör bağlanma domaini (RBD) ve korun- muş reseptör bağlanma motifi (RBM) içerir. S2 alt birimi ise füzyon peptidi (FP), heptad tekrarı (HR) 1 ve 2 olmak üzere üç operasyonel domaine sahiptir ${ }^{6,7}$.

Viral S proteini, virüsün bağlanmasına ve anjiyotensin dönüştürücü enzim 2 (ACE2) yoluyla konakçı hücreye daha fazla girmesine aracilık eder. Viral antijenlerin veya viral gen sekanslarının uygulanmasını kullanan COVID-19 aday aşıların çoğunluğu, viral S proteinlerine karşı nötrleştirici antikorları indüklemeyi, insan ACE2 reseptörü yoluyla alımını önlemeyi ve bu nedenle enfeksiyonu engellemeyi amaçlamaktadır.

SARS-CoV-2 hastalarında hafif/ortadan şiddetliye, hızla ilerleyen ve fulminan hastalık arasında değișen çok çeşitli klinik bulgular görülmektedir. SARS-CoV-2'nin semptomları spesifik değildir ve hastalık asemptomatikten şiddetli pnömoniye kadar değişebilmektedir. Asemptomatik SARS-CoV-2 vakalarının insidansı \%1.6 ila \%51.7 arasında değişmektedir ve bu kişiler tipik klinik semptomlar veya bulgular göstermemektedir ve akciğer bilgisayarlı tomografisinde (BT) belirgin anormallikler görülmemektedir. COVID-19 enfeksiyonlarında genellikle ateş, öksürük, dispne, miyalji, halsizlik, baş ağrısı, boğaz ağrısı, tat veya koku kaybı, polipne ve diğer semptomlar görülür. Ağır vakalarda, akciğerlerdeki hava keseciklerine sıvı dolması sonucu gelişen, septik şoka sebep olan Akut Respiratuar Distress Sendromu'na (ARDS) neden olabilir $^{8-10}$. Tian ve ark. sindirim sistemi ile ilgili vaka raporlarından ve retrospektif klinik çalışmalardan elde ettikleri bilgiler ışığında anoreksi, ishal, kusma, bulantı, karın ağrısı ve gastrointestinal kanamayı içeren gastrointestinal semptomların, vakaların \%3\%79'unda ortaya çıktığı sonucuna varmışlardır ${ }^{11}$.

Şu anda COVID-19'un erken tespiti için kullanılan en yaygın moleküler yöntem, ters transkripsiyon polimeraz zincir reaksiyonudur (RT-PCR). Klinikte COVID19 enfeksiyonu ve patolojik durumu teşhis etmek için RT-PCR bazlı moleküler tanı yöntemi ve BT bazlı tıbbi görüntüleme teknolojileri kullanılmaktadır. Ayrıca, hastanın antikorlarını tespit etmeyi amaçlayan serolojik testlerde kullanılmaktadır.

Polimeraz zincir reaksiyonu (PCR), enfeksiyöz patojenleri tespit etmek için altın standart olarak kabul edilir ve daha önceki salgınlarda da CoV'leri tespit etmek için başarıyla kullanılmıştır. PCR, primerler spesifik olarak viral genomun spesifik bölgesine bağlandığından DNA/ RNA hedefine karşı oldukça duyarlıdırlar. Salgının başlangıcında SARS-CoV-2 salgınına yanıt olarak tüm dünyadaki laboratuvarlarda RTPCR kantitatif test yöntemi öncelikli olarak kullanılmiştır.

İmmünoglobulinler $M$ ve $G$ (IgM ve IgG), SARSCOV-2 serolojik tanısı için en sık kullanılan biyobelirteçlerdir. SARS-CoV-2 ile şu anda veya daha önce enfekte olmuş olanları tespit etmek için kullanılan çeşitli tanı testleri, IgM ve IgG antikorlarının varlığını tespit eden kan örneği analizine dayanarak geliştiril- 


\section{COVID-19 Tanı Testleri, Tedavisindeki Aşılar ve İlaçlar}

miştir. IgM antikorları ilk olarak enfeksiyondan sonraki ilk birkaç hafta boyunca serumda saptanabilir hale gelir ve daha sonra izotip IgG'ye dönüşür. Bu nedenle, IgM erken evre enfeksiyonun bir göstergesini sağlarken, IgG mevcut veya önceki enfeksiyonu gösterir. Bu test, SARS-CoV-2 için epidemiyoloji ve aşı geliştirmede önemli bir rol oynar ve hem kisa hem de uzun dönem antikor yanıtını, antikor miktarını ve çeşitliliğinin bir değerlendirmesini sağlar. Bu testlerin yapılması kolaydır, hızlı bir yanıt sağlar ve bu nedenle viral enfeksiyonları teşhis etmek için yüksek çıktılı bir yöntemdir ${ }^{12}$.

COVID-19'un patogenezini iki ana sürecin yönlendirdiği düşünülmektedir. Enfeksiyonun başlangıcında, hastalık öncelikle SARS-CoV-2 koronavirüsünün replikasyonu ile gerçekleşmektedir. Daha sonra enfeksiyon sırasında, hastalık, doku hasarına yol açan virüse karşı abartılı bir bağışıklık/enflamatuar tepki oluşturmaktadır. Bu anlayışa dayanarak, antiviral tedavilerin hastalığın erken evrelerinde en büyük etkiye sahip olacağı beklenmektedir, immünosupresif/ antiinflamatuar tedavilerin ise COVID-19'un ileri aşamalarında daha faydalı olması muhtemeldir ${ }^{13}$.

Dünya çapında SARS-CoV-2'ye karşı terapiler ve profilaktik aşılar geliştirmek için çabalar sürmektedir. Terapötikler hastaneye yatış süresini kısaltmayı ve enfekte hastaların sağkalımını arttırmayı amaçlarken, profilaktik aşılar SARS-CoV-2'ye karşı koruyucu bağışıklık oluşturmayı amaçlamaktadır. Sınırlı ventilatör ve hastane kapasitesi gibi acil pandemik ortam sonuçları göz önüne alındığında, SARS-CoV-2'ye karşı başarılı profilaktik aşıların geliştirilmesi kritik öneme sahiptir.

Aşılar her yıl milyonlarca hayat kurtarmaktadır. Aşılar, hedefledikleri virüsleri ve bakterileri tanımak ve savaşmak için vücudun doğal savunmasını (immun sistem) hazırlama ve eğitme yoluyla çalışırlar. Aşılamadan sonra, vücut hastalığa neden olan virüs, bakteri gibi mikroplara maruz kalırsa, hemen onları yok etmeye ve hastalığı önlemeye hazır halde bulunmaktadır.

18 Şubat 2021 itibariyle, ülkelerde üç platformda en az yedi farklı aşı kullanıma sunulmuştur. Aşılama da tüm ülkelerdeki savunmasız popülasyonlara öncelik verilmiştir. 14 Haziran 2021 tarihinde SARS-CoV-2 Vaccine ClinicalTrials.gov arama verilerine göre 194 pre-klinik ve klinik aşı çalışması bulunmaktadır ${ }^{14}$. Bunlardan 46 tanesi Faz 3 aşamasındadır ${ }^{15}$.

DSÖ verilerine göre dünya genelinde 14 Haziran 2021 tarihi itibari ile 185 preklinik, 102 klinik aşamada olmak üzere toplam 287 aşı adayı bulunmaktadır ${ }^{16}$. Dünyanın dört bir yanındaki bilim adamları COVID19 için potansiyel birçok aşı geliştirmektedirler. Bu aşıların tümü, COVID-19'a neden olan virüsleri vücudun immün sistemine güvenli olarak tanıtmak ve bunları bloke etmek için tasarlanmıştır.
COVID-19 için birkaç farklı potansiyel aşı türü geliştirilmektedir. Aşılar yaygın olarak kullanılan klasik aşı platformları (virüs bazlı, protein bazlı ve virüs benzeri parçacıklar) ve yeni jenerasyon platformları (viral vektör, nükleik- asit bazlı aşılar (RNA, DNA), antijen sunan hücreler) olmak üzere iki platforma ayrılmaktadirlar ${ }^{17}$.

Virüs bazlı aşılar, artık bulaşıcılığı olmayan inaktive virüs veya canlı zayıflatılmış virüsten oluşabilirler. İnaktive virüslerin hepsi çoğalmadığından, immün sistemi uyarmak için adjuvanlar gerektirirler. Canlı zayıflatılmış virüs aşıları, patojenik özelliklerini kaybedene ve enjeksiyon akabinde hafif bir enfeksiyona neden olana kadar klasik olarak hücre kültüründe pasajlanarak üretilmektedirler.

Protein bazlı aşılar, güvenli immün yanıt oluşturmada, COVID-19 virüsün dışını taklit eden zararsız protein parçaları veya protein kabuklarını kullanırlar. Protein bazlı aşılar, virüs veya virüsle enfekte hücrelerden, rekombinant protein veya virüs benzeri parçacıklardan saflaştırılmış bir proteinden oluşabilirler.

Virüs benzeri parçacıklar, bir virüs parçacığı oluşturmak için gerekli olan yapısal viral proteinlerden oluşur ancak viral genom ve yapısal olmayan proteinlerden yoksundurlar. $\mathrm{Bu}$ aşılar, güçlü bir immün yanıtı indüklemek için bir adjuvan gerektirir.

Viral vektör aşıları, hastalığa sebep olamayan ancak immün yanıt oluşturmak için koronavirüs proteinleri üretmek için platform işlevi gören güvenli virüsleri kullanılırlar. Viral vektör aşıları, sıklıkla patojeniteyi azaltmak için zayıflatılmış bir rekombinant virüsten (yani viral vektörden) oluşur, viral antijenleri kodlayan genler, rekombinant DNA teknikleri kullanılarak klonlanmaktadırlar. Vektör aşılarının replike ve replike olmayan olmak üzere iki türü vardır.

RNA ve DNA aşıları, güvenli immün cevabı tetikleyen bir protein üretmek için genetik olarak tasarlanmış olan RNA veya DNA'yı kullanan son teknoloji yaklaŞımlardır ${ }^{18}$.

Nükleik asit bazlı aşılar DNA veya mRNA'dan oluşurlar ve yeni virüsler ortaya çıktığında kolaylıkla adapte edilebilirler. $\mathrm{Bu}$ sebeple bunlar klinik çalışmalara giren ilk COVID-19 aşıları arasında yer almışlardır. Kendi kendini kopyalayan RNA aşıları, hücre başına daha fazla aşı antijeni eksprese edildiğinden daha düşük doz kullanarak koruyucu immüniteyi indüklemesi muhtemeldir. mRNA çok kararlı değildir. Bu yapılar degradasyonu önlemek için modifiye nükleositler içerirler. Hücrelere mRNA (mesajcı RNA) girmesini sağlamak için bir taşıyıcı molekül gereklidir. En yaygın olarak lipid nanopartiküller kullanılmaktadır. Nükleik asit bazlı aşılar humoral ve hücresel immün yanıtı indükler, ancak çoklu dozlar gereklidir. Antijen sunan hücreler, bağışıklık sisteminin aşıya verdiği yanıtta önemli bir bileşendir. Bilindiği üzere dendritik hücreler bireyden alınır, daha sonra istenen 
antijeni sunmak için manipüle edilir ve aynı bireye geri infüze edilir ${ }^{17}$.

\section{SARS-Cov-2 İçin Klinik Denemelerde Olan Mev- cut Aşı Adayları:}

ABD'de mevcutta olan ilk iki aşı (Pfizer-Biontech ve Moderna) mRNA aşılarıdır. Diğer aşılar (ABD'de Janssen-Johnson \& Johnson ve ABD dişındaki AstraZeneca, Sputnik-V ve Casino) insan ve primat adenovirüs vektörleri kullanılarak yapılan aşılardır. ABD dışında mevcut olan başka bir aşı türü ise inaktive tüm virüs SARS-CoV- 2 aşısıdır (Bharat Biotech ve Sinovac). Bu aşıların hiçbiri canlı aşı değildir.

\section{mRNA-1273 Aşlsı (Moderna/US NIAID)}

Boston merkezli Moderna Therapeutics, SARS-CoV2'nin genom sekanslamasından 63 gün sonra klinik çalışmalara giren ilk aşı adayını üretmek için Ulusal Alerji ve Enfeksiyon Hastalıkları Enstitüsü (NIAID) ile ortaklık kurmuştur. Bu aşı, konakçı immün hücreler yoluyla alımını artıran bir lipid nanopartikül (LNP) vektöründe enkapsüle edilmiştir. SARS-CoV-2, spike (S) proteininin stabilize edilmiş prefüzyon formunun sentezi için bilgi içeren mRNA molekülüne dayanmaktadir.

mRNA-1273 aş1sı, proteini eksprese etmek için mRNA kullanma prensibine dayanan ABD şirketi Moderna tarafindan üretilmektedir. mRNA-1273, SARS CoV-2 glikoproteinini transmembran bağlantı ve intakt S1 (bağlanma)- S2 (füzyon) bölünme bölgesi ile kodlamaktadır. 30 Kasım 2020 tarihinde Moderna, 196 doğrulanmış COVID-19 vakada yapılan birincil etkinlik analizi sonuçlarını açıklamıştır. Şiddetli hastalık geliştiren 30 birey arasında, bu vakaların hiçbiri aşı adayı ile aşılanmamış olup bu da mRNA-1273'ün ağır hastalığa karşı güçlü bir şekilde koruyucu olduğunu göstermiştir. 8 Aralık 2020'de ABD G1da ve İlaç İdaresi (FDA) bu aşı için 18 yaşından büyük bireylerde acil kullanım izni yayınlamıştır.

30 Aralık 2020 tarihinde mRNA-1273 aşısının Faz 3 denemesinden elde edilen güvenlik ve etkinlik sonuçları, New England Journal of Medicine'de yayınlanmış olup aşı adayının \%94.1 etkinlik ve güvenlik profili doğrulanmıştır. 4 Ocak 2021'de İsrail, Moderna'nın aşı adayını da onaylamıştır ve daha sonra Avrupa İlaç Ajansı (EMEA) aşıyı yetkilendirme için öneride bulunmuştur ${ }^{19}$.

Moderna Inc. Faz 3 klinik çalışmalarında \%94.5 etkinlik elde ettiğini açıklamıştır ve son zamanlarda ABD'de FDA acil durum onayı almıştır. $\mathrm{Bu}$ aşının birincil dezavantajı düşük yarı ömrü olması, düşük stabilite ve viral vektörlerden 10 kat daha düşük bir transfeksiyon oranı sergilemesidir ${ }^{12}$.

\section{BioNTech/Pfizer Aşısı (Almanya /ABD) (20)}

11 Aralık 2020'de FDA, lipit nanopartikülle formüle edilen COVID-19 hastalığına neden olan SARS-CoV2 virüsün prefüzyon spike glikoproteinini kodlayan nükleosit-modifiye mRNA aşısı olan Pfizer-BioNTech COVID-19 (BNT162b2) aşısı için 16 yaş ve üstü bireylerde COVID-19 hastalığının önlenmesi için acil kullanım iznini (EUA) yayınlamıştır. PfizerBioNTech COVID-19 aşısı ile aşılama, 3 hafta arayla intramusküler olarak 2 doz (her biri $30 \mu g, 0.3 \mathrm{~mL}$ ) uygulanmaktadır. Denemeler kapsamında BioNTech ve Pfizer'in mRNA aşısının BNT162b1, BNT162b2, BNT162a1 ve BNT162c2 olmak üzere dört aday1 vardır. Bunların her biri farklı bir mRNA formatı ve antijenini temsil etmektedir. BNT162b1 ve BNT162b2 ikisi de nükleosit modifiye mRNA (modRNA) aşısıdır. BNT162b1, spike proteininin trimerize reseptörbağlama domainini kodlarken, BNT162b2 tam spike proteinini kodlamaktadır. Öte yandan, BNT162a1 üridin mRNA (uRNA) bazlı bir aşıdır ve BNT162c2 kendi kendini kopyalayan mRNA (saRNA) bazlı bir aşıdir $^{21}$.

Kasım ayında büyük miktarda tanıtıma neden olan aşı, Alman şirketi BioNTech ve Pfizer tarafından geliştirilen aşıdır. Faz 1 randomize plasebo kontrollü klinik çalışmalardan elde edilen sonuçlar, BNT162b2'nin hem genç (18-55 yaş) hem de yaşlılarda (65-85 yaş) minimum yan etki yarattığını gösterilmiştir. Ayrıca, bu çalışmalarda BNT162b1 ve BNT162b2 olmak üzere iki farklı aday değerlendirilmiştir. Her iki adayın da benzer şekilde aşılananlarda SARS-CoV-2'ye karş1 yüksek doza bağl1 nötralize edici antikor titrelerinin üretimini indüklemiştir. BNT162b1 ve BNT162b2, sentetik mRNA'nın enjekte edildiği ve konakçı tarafından hızla proteine çevrildiği mRNA aşılarıdır. mRNA, genetik bilgi taşıyan oldukça yeni bir ilaç sinifidir.

Pfizer ve BioNTech tarafindan gerçekleştirilen çalışma verilerine göre 21.720'si BNT162b2 ile aşılanan 21.728'i plasebo olmak üzere toplam 43.448 katılımcıya enjeksiyon yapılmıştır. $\mathrm{Bu} 43.448$ katılımcıdan 170'inde COVID-19 gelişmiştir. Bunlar arasında 162 'sinin plasebo grubuna, 8'inin de aşı adayı ile aş1lanan gruba ait olduğu tespit edilmiş ve bu verilerle BNT162b2 aşısının COVID-19'un önlenmede \%95 etkili olduğu bulunmuştur (\%95 güvenilir aralık, 90.397.6). Yaş, cinsiyet, 1rk, etnik köken, temel vücut kitle indeksi ve birlikte var olan koşulların varlığı ile tanımlanan alt gruplarda benzer aşı etkinliği (genellikle \%90-\%100) gözlenmiştir. BNT162b2'nin güvenlik profili, enjeksiyon bölgesinde kısa süreli, hafif ila orta şiddette ağrı, yorgunluk ve baş ağrısı ile karakterize edilmiştir ${ }^{22}$.

Her iki aşının da birbirine benzer, hem lokal (ağrı, eritem, şişme ve lenfadenopati) hem de sistemik yan etkileri (ateş, baş ağrısı, miyalji, bulantı veya kusma) içeren güvenlik endişesi olmayan yan etki profilleri 


\section{COVID-19 Tanı Testleri, Tedavisindeki Aşılar ve İlaçlar}

rapor edilmiştir ${ }^{23}$. Așının ilk dozu immün sistemi güçlendirirken, ikinci doz immün yanıtı güçlendirmektedir ${ }^{24,25}$. Protein subunit aşı adayları inaktive patojen aşılarına benzer şekilde, genellikle son derece uygun bir güvenlik profili sergiler. Ancak çoklu destek dozları gerektirir ve düşük dereceli hücresel tepkiler ortaya çıkarmaktadırlar.

\section{Novavax Aşlsı (Gaithersburg, $M A, A B D$ )}

Maryland merkezli bir biyoteknoloji şirketi olan Novavax, bir bakulovirüs-Sf 9 sisteminde eksprese edilen ve Matrix M1 adlı bir adjuvan içeren rekombinant SARS-CoV-2 S glikoprotein nanopartikül aş1 geliştirmiştir. Şirketin nanoparçacık teknolojisi kullanılarak ürettiği NVX-CoV2373, kararlı bir prefüzyon proteindir. NVX-CoV2373 ilk olarak aşı ile aşılanan makaklarda (Macaca fascicularis) test edilmiştir. Bu aşılanma sonrası maymunların COVID-19'a karş1 korunduğu ve herhangi bir üst veya alt hava yolu enfeksiyonu veya akciğer hastalığı belirtisi göstermediği gözlenmiştir ${ }^{26}$.

Novavax, protein bazlı COVID-19 aşı adayı NVXCoV2373'ün, Birleşik Krallık'ta (İngiltere) yapılan Faz-3 klinik çalışmasında \%89.3'lük bir aşı etkinliğ ile birincil hedefi karşıladığını açıklamıştır ${ }^{27}$.

LV-Smenp-DC Aşlsl (Shenzhen Geno-immün Tıp Enstitüsü, Çin)

LV-Smenp-DC aşısı, SARS-CoV-2 yapısal proteinlerinin korunmuş domainlerini eksprese eden ve Smenp minigenlerini proteazını kullanarak lentiviral vektör ile dendritik hücrelerin (DC) mühendisliği ile hazırlanmaktadir ${ }^{28}$

\section{INO-4800 (Inovio Pharmaceuticals, ABD)}

INO-4800, SARS-CoV-2 genetik sekansına dayanan DNA plazmid bazlı bir aşıdır. Inovio Pharmaceuticals biyoteknoloji şirketi tarafından, Cellectra adı verilen el tipi bir akıllı cihaz kullanarak intramusküler veya intradermal olarak optimize plazmidleri doğrudan hücrelere taşımak için tasarlanmıştır ${ }^{29}$. Şu anda ABD genelinde 6578 sağlıklı bireyde güvenlik, tolere edilebilirlik ve immünojenisiteyi belirlemek için faz 2/3 klinik çalışmalarda bulunmaktadır ${ }^{30}$.

24 Aralık yayınlanan makalede $18-50$ yaş arası 40 gönüllü üzerinde yapılan bir faz 1 çalışmasından elde edilen ara verilerin sonuçlarına göre 1.dozdan 8 hafta sonra toplam 11 lokal ve sistemik advers olay (AEs) tespit edilmiş olup bunlardan altısı aşı ile ilgili olarak kabul edilmiştir. İlgili altı yan etkiden beşi, enjeksiyon bölgesi ağrısı ve eritem dahil olmak üzere enjeksiyon bölgesi reaksiyonlarıdır. Aşı ile ilişkili grade 1 sistemik yan etki olarak da mide bulantısı tespit edilmiştir. Ayrıca INO-4800 dengeli humoral ve hücresel immün tepkiler üretmiş iki doz INO-4800 aşılanmayı takiben antikor veya $\mathrm{T}$ hücresi yanıtı ya da her ikisini de göstermiştir ${ }^{29}$.

Oxford / Astra Zeneca Aşısı (İngiltere / ABD)- Janssen Aşlsı (Hollanda / ABD)

Hem AZD-1222 (ChAdOx1 nCoV-19) olarak da adlandırılan Oxford Üniversitesi/AstraZeneca (ChAdOx1) hem de Janssen (Ad26.COV2) aşıları spike geni ile değiştirilen E1 geninin silinmesiyle inaktive edilen adenovirüslerin genetik modifikasyonuna dayanmaktadır. Janssen Ad26.Cov2 aşısı insan adenovirüsüne Oxford aşısı şempanze (ChAdOx1) adenovirüsüne dayanmaktadır. 8 Aralık 2020'de üretici, AZD1222'nin kabul edilebilir bir güvenlik profiline sahip olduğunu ve hastaneye yatış veya ciddi reaksiyonlar olmaksızın semptomatik COVID-19'a karşı etkili olduğunu açıklamıştır. AZD-1222'nin şu anda ABD, İngiltere, Hindistan ve diğer ülkelerde Faz 3 klinik çalışmaları yürütülmektedir. Son zamanlarda, İngiltere ve Hindistan AZD-1222'nin acil kullanımını onaylamış ve aşılamaya başlanmıştır.

23 Nisan- 21 Mayıs tarihleri arasında İngiltere'deki Oxford Üniversitesi Klinik Aşı Bilimi ve Tropikal Tıp Merkezinin de içinde bulunduğu beş merkezde gerçekleşen gönüllü-kör, çok merkezli, randomize kontrollü Faz 1/2 çalışması yapılmıştır ve 15 Ağustos 2020 'de ön rapor olarak yayınlanmıştır ${ }^{31}$. Çalışma ChAdOx1 nCoV-19 ( $n=543)$ ve MenACWY ( $n=534)$ olmak üzere 1077 gönüllüde gerçekleştirilmiştir. Çalışmada birçoğu ağrı, ateş, titreme, kas ağrısı, baş ağrısı ve halsizlik dahil olmak üzere lokal ve sistemik reaksiyonlar ChAdOx1 nCoV-19 grubunda daha yaygın görülmüş olup; profilaktik parasetamol kullanımı ile azaltılmıştır. ChAdOx1 nCoV-19 ile ilgili ciddi advers etkiler gözlenmemiştir. ChAdOx1 nCoV-19 grubunda, S proteinine özgü T hücresi yanıtlarının 14 . günde zirveye ulaştığı anti-spike $\operatorname{IgG}$ yanıtlarının ise 28. güne kadar yükseldiği bulunmuştur ${ }^{31}$. 30 Mayıs-8 Ağustos 2020 tarihleri arasında gerçekleşen faz 2/3 çalışmasında 560 gönüllü çalışmaya alınmıştır ve gönüllüler rastgele olarak 18- 55 yaş, 56- 69 yaş ve 70 yaş ve üzeri 3 gruba deneysel aşı ve kontrol grubuna ayrılmışlardır ${ }^{32}$.

ChAdOx1 nCoV-19 aşısı verilen gönüllülerde kontrol aşısı verilenlere göre lokal ve sistemik reaksiyonlar daha yaygın bulunmuş ve daha önce bildirilenlere (enjeksiyon bölgesi ağrısı, ateş, kas ağrısı, baş ağrısı) benzer bulunmuştur. Ancak daha yaşlı yetişkinlerde ( $\geq 56$ yaş) genç yetişkinlere göre daha az yaygın bulunmuştur. Çalışmada, ChAdOx1 nCoV-19 aşısının yaşlı yetişkinlerde gençlere göre daha düşük bir reaktojenite profili ile güvenli ve iyi tolere edildiğini gösterilmiştir. İmmünojenite, ikinci aşılamadan sonra tüm yaş gruplarında benzer bulunmuştur. ChAdOx1 nCoV-19 aşısının, 70 yaş ve üstü yetişkinler de dahil olmak üzere tüm yaş gruplarında tek dozdan 28 gün 
sonra SARS-CoV-2 spike glikoproteinine ve RBD'ye spesifik bir antikor yanıtını indüklediği gösterilmiştir ${ }^{32}$. 27 Şubat 2021'de FDA, SARS-CoV-2'nin neden olduğu COVID-19 hastalığının önlenmesi için üçüncü aşı olan Janssen COVID-19 aşısının ABD'de 18 yaş ve üstü bireylerde kullanımı için acil kullanım izni (EUA) yayınlamıştır ${ }^{33}$. Janssen'in faz II çalışması, 65 yaş ve üstü sadece 15 gönüllü ile yapılmıştır ve advers etki oranları $\% 36$ oranı ile 65 yaş ve üstü olan katılımcılarda genç (\%64) olanlardan daha düşük bulunmuştur $^{34}$. Janssen COVID-19 aşısı olan bazı kişilerde düşük trombosit seviyeleri ile birlikte beyin, karın ve bacaklarda damarlarda pıhtı görülmüştür. Bu pıhtı ve düşük trombosit seviyeleri çoğu 18 ila 49 yaş arasındaki kadınlarda görülmekle birlikte semptomlar aş1lamadan yaklaşık bir ila iki hafta sonra başlamıştır ${ }^{33}$. 13 Nisan 2021'de FDA ve CDC (Hastalık Kontrol ve Önleme Merkezleri), beyindeki büyük kan damarlarında serebral venöz sinüs trombozu (CVST) olarak adlandırılan bir tür kan pıhtısının ciddi yan etki raporları nedeniyle Janssen COVID-19 aşısının kullanımında bir duraklama önermiştir. FDA ve CDC'nin, aşı kullanımını duraklatma önerisinden sonra yeni bilgiler de dahil olmak üzere mevcut tüm verileri gözden geçirilmiştir. Bu veriler, Janssen COVID-19 aşısının bilinen ve potansiyel faydalarının 18 yaş ve üstü bireylerde bilinen ve potansiyel risklerinden daha ağır bastığını değerlendirmelerine sebep olmuştur.

\section{Corona Vac Aşısı (SinoVac Inc., Çin)}

Corona Vac, Sinovac Research and Development Co. tarafından geliştirilen inaktive edilmiş bir viral vektör aşısıdır. Çin sağlık çalışanları gibi yüksek riskli grupları aşılamak için 28 Ağustos 2020 tarihinde tüm inaktive SARS-CoV-2 virüsünü kullanarak Corona Vac aşısının acil kullanımını onaylamıştır.

Plasebo veya CoronaVac iki farklı aşı dozu (3 veya 6 $\mu \mathrm{g} / 0.5 \mathrm{ml}$ ) alan 18 ila 59 yaşları arasında 600 sağlıklı gönüllüde yapılan faz 2 randomize, çift-kör, plasebokontrollü doz yükseltme güvenliği ve immünojenite çalışmaları yapılmıştır. Corona Vac her iki dozda da iyi tolere edilmiş ve advers reaksiyonların çoğu hafif bulunmuştur. Bildirilen semptomların en yaygın olanı enjeksiyon bölgesinde ağrıdır. Her iki Corona Vac dozunun, aşılanan bireylerin \%90'ından fazlasında serokonversiyona neden olmuştur ${ }^{35}$.

\section{Ad5-nCoV Aşısı (Cansino Biologics Inc, Pekin Biyo- teknoloji Enstitüsü)}

Çin Pekin Biyoteknoloji Enstitüsü ve Cansino Biologics tarafından geliştirilen Ad5-nCoV, SARS-CoV2'nin rekombinant S proteinini eksprese eden rekombinant, replikasyon-defektif bir adenovirüs tip-5 vektör (Ad5) aşısıdır. E1 ve E3 genlerinden yoksun Ad5 vektöründe plazminojen aktivatör sinyal peptid geni ile optimize edilmiş tüm $\mathrm{S}$ proteininin geninin klon- lanmasıyla hazırlanmıştır. Corona Vac aşısının şu anda 14 günlük aralıkla iki dozluk bir enjeksiyon rejimi ile faz 3 klinik çalışmaları bulunmaktadır.

25 Haziran 2020'de, Çin Merkez Askeri Komisyonu, bir yıl boyunca Ad5-nCoV aşısını "özel olarak ihtiyaç duyulan ilaç" olarak kullanılmasını onaylamıştır. Şu anda Rusya, Suudi Arabistan ve Pakistan'da faz 3 klinik çalışma aşamasındadır. Mart 2020'de Çin Wuhan'da bir rehabilitasyon merkezinde aşı adayının tek merkezli, açık etiketli, randomize olmayan, doz yükseltme faz 1 denemesi yapılmıştır. Bu çalışmada 195 kişiden 108 'ine düşük doz $(n=36)$, orta doz $(n=36)$ veya yüksek doz $(n=36)$ olmak üzere aşı uygulanmıştır. Aşılanan 108 kişide en yaygın görülen advers reaksiyonu, enjeksiyon bölgesinde 58 kişide (\%54) ağrı olmuştur ve en sık bildirilen sistematik advers reaksiyonu 50 kişide ateş (\%46), 47 kişide yorgunluk (\%44), 42 kişide baş ağrısı (\%39) ve 18 kişide kas ağrısı (\%17) olmuştur. Aşılamadan sonraki 28 gün içinde ciddi bir yan etki kaydedilmemiştir. 14. günde ELISA antikorları ve nötrleştirici antikorlar önemli ölçüde artmış ve aşılamadan 28 gün sonra zirveye ulaşmıştır. Spesifik T hücresi yanıtı ise aşılamadan sonraki 14. günde zirveye ulaşmıştır ${ }^{36}$.

\section{Sputnik V Aşısı (Gam-COVID-Vac, Rusya)}

Sputnik V olarak da bilinen Gam-COVID-Vac Rusya'daki Gamaleya Araştırma Enstitüsü bilim adamları, ilk bağışıklamadan sonra viral vektöre karşı ortaya çıkan antikorlara bağlı olarak azaltılmış immünojenite sorununu aşmak için şimdiye kadar tek olan heterolog birincil-ikincil SARS-CoV-2 aşı adayını geliştirmişlerdir. Birincil aşılama için kullanılan adenoviral vektör serotipi, ikincil olarak kullanılan adenoviral serotipten farklıdır. Rekombinant adenovirüs tip 26 vektör (rAd26), Rekombinant adenovirüs tip 5 vektör (rAd5) olmak üzere iki vektör içeren SARS-CoV-2 spike glikoproteini için gen taşıyan heterolog COVID-19 aşısıdır.

$\mathrm{Bu}$ nedenle, ilk aşılama sırasında $\mathrm{S}$ proteinine genetik bilgiyi taşımak için replikasyon- defektif Ad26 ve ikincisi için rekombinant replikasyon- defektif Ad5 iki vektörlü adenovirüs aşısı geliştirilmiştir ${ }^{37}$.

Rusya Savunma Bakanlığı'na bağlı Burdenko Hastanesin'de askeri ve sivil gönüllülerde yapılan faz $1 / 2$ randomize olmayan çalışmanın bulguları, rekombinant adenoviral vektörler rAd26-S ve rAd5-S'ye dayanan heterolog aşının güvenli, iyi tolere edildiğini ve sağlıklı katılımcıların \%100'ünde güçlü humoral ve hücresel immün yanıtları indüklediğini göstermektedir. Bildirilen tüm advers etkiler çoğunlukla hafif bulunmuştur. En sık görülen sistemik ve lokal reaksiyonlar, rekombinant viral vektörlere dayanan aşılar için tipik olan enjeksiyon bölgesinde ağrı, hipertermi (vücut $1 \mathrm{~s} 1 \mathrm{~s} 137-38^{\circ} \mathrm{C}$ ), baş ağrısı, asteni ve kas ve eklem ağrısı bulunmuştur $^{38}$. 24 Kasım'da, Sputnik V ikinci faz 3 ara raporunun sonuçlarında, heterolog immunizasyon 


\section{COVID-19 Tanı Testleri, Tedavisindeki Aşılar ve İlaçlar}

rejiminin her iki dozunu aldıktan bir hafta sonra 18.794 kişiden elde edilen veriler analiz edilmiş bu aşı adayının \%91.4 etkinliği ortaya konulmuştur ${ }^{39}$.

\section{Türkiye'de Yürüyen Așı Çalıșmaları}

Ülkemizde 13 Haziran 2021 tarihi itibari ile 48.721 ölümle 5.330.447 toplam vaka görülmüş olup toplam 33.765.656 aşı yapılmıştır ${ }^{40}$. Türkiye'de yeni tip koronavirüse karşı geliştirilecek aşılar için Türkiye Sağlık Enstitüleri Başkanlığı (TÜSEB) ve Türkiye Bilimsel ve Teknolojik Araştırma Kurumu (TÜBİTAK) tarafindan hızlıca harekete geçirilen destekler ile 17 yerli aşı çalışması yürütülmektedir. ClinicalTrials.gov'da "COVID-19 Turkey vaccine" arama verilerine göre TÜSEB destekli Erciyes Üniversitesi ERUCOV-VAC inaktif aşısının faz 1, 2, Koçak Farma Koçak-19 inaktif adjuvanlı COVID-19 aşısının faz 1, TÜBİTAK destekli VETAL Inc. Monitor CRO inaktif SARSCoV-2 aşının faz 1, TÜBİTAK destekli Dr. Abdurrahman Yurtaslan Ankara Onkoloji Eğitim ve Araştırma Hastanesi Monitor CRO, Nobel Pharmaceuticals VLP (Virüs-benzeri parçacık) aşının faz 1, çalışmaları devam etmektedir. Ayrıca CoronaVac inaktif aşısının Faz 3 çalışmaları Ankara Üniversitesi Tıp Fakültesi, Hacettepe Üniversitesi Tıp Fakültesi olmak üzere 25 merkezde çalışmaları sürmektedir. Pfizer-BioNTech mRNA aşısının Faz 1, 2, 3 çalışmaları da ülkemizde devam etmektedir ${ }^{41}$. Yerli imkânlarla geliştirilmekte olan, TÜSEB tarafından desteklenen intranazal COVID-19 aşı projesi, Faz I aşamasına geçmek üzeredir. Marmara Üniversitesi, Akdeniz ÜniversitesiHacettepe Üniversitesi, Yıldız Teknik Üniversitesi, Atatürk Üniversitesi yürütücülüklerinde Ar-Ge çalışmaları ve hayvan deneyleri devam etmektedir ${ }^{42}$. Ayr1ca Ege Üniversitesi, COVID-19'a karşı koruma sağlamak üzere İlaç Geliştirme ve Farmakokinetik Araştırma Uygulama Merkezi (ARGEFAR) bünyesindeki EÜ Aşı ve Araştırma Geliştirme Grubu ile TÜBİTAK desteğiyle DNA Aşısı geliştirmektedir. Çalışma grubu, koronavirüse karşı dört farklı DNA aşısı prototipi tasarlamışlardır. Hayvan deneylerini ve farelerde aşılama ile uyarılan bağışıklık yanıtını incelemişlerdir ve DNA aşısı prototiplerinden iki tanesinin güçlü hücresel ve humoral bağışıklık yanıtı oluşturduğunu saptamışlardır. Bu iki aşı adayıyla gönüllü insanlarda faz çalışmalarına geçmeyi planlamaktadırlar ${ }^{43}$.

\section{SARS-Cov-2 İçin Klinikte Kullanılan Antiviral İlaçlar}

COVID-19 tedavisi için değişik antiviral ilaçlar salgın boyunca denenmiştir. Şu anda COVID-19 tedavisi için onaylanan bir antiviral ajan bulunmamaktadır. COVID-19 tedavisinde kullanılan antiviraller arasında remdesivir, favipiravir, umifenovir, lopinavir/ ritonavir ve ribavirin bulunur. Bu antivirallerin monoterapide ve başka ilaçlarla kombinasyon halinde kullanımı- nın değerlendirilmesine dair klinik araştırmalar sürmektedir $^{44}$.

\section{Favipiravir}

Favipiravir, 2014 yılında Japonya'da Toyama Chemical tarafından geliştirilen RNA'ya bağımlı RNA polimerazının selektif inhibitörüdür. Bazı ülkelerde influenza, ebola ve norovirüs tedavisi için onaylanmıştır ${ }^{45}$. Favipiravir iyi karakterize edilmiş bir güvenlik profiline sahiptir. Yaygın görülen yan etkiler arasında gastrointestinal yan etkiler, ürik asit yükselmesi, nötrofil sayısında azalma, aspartat aminotransferaz (SGOT) ve alanin transaminaz (SGPT) artışı, psikiyatrik semptom reaksiyonları ve kan trigliseridlerinde yükselme yer almaktadır. Düşük ve yüksek favipiravir dozları arasında benzer yan etki oranları gözlenmektedir ${ }^{46}$.

Ön klinik sonuçlar, favipiravirin, lopinavir-ritonavir ile karşılaştırıldığında COVID-19 hastalarında göğüs görüntülemesinde anlamlı ölçüde daha fazla iyileşme göstermektedir (favipiravir ile \%91.4, lopinavirritonavir ile \%62.2 iyileşme). Favipiravir uygulanan hastalarda lopinavir-ritonavir alanlara kıyasla daha hızlı viral klirens (4 güne karşı 11 gün) ve daha az advers olay (\%11.4'e karş1 \%55.6) gözlenmiştir ${ }^{47}$.

Çin'de yürütülen favipiravir ve umifenovir kullanımını karşılaştıran randomize kontrollü bir klinik çalışmada, favipiravir grubunda öksürük ve ateş şikayetleri bulunan hafif ve orta şiddetli COVID-19 hastalarının umifenovir ile tedavi edilen hastalara kıyasla daha kısa sürede iyileştiği gözlemlenirken oksijen terapisi gören veya solunum desteğine gereksinim duyan hastalarda herhangi bir farklılık gözlenmemiştir ${ }^{48}$. Ancak anormal karaciğer fonksiyon testleri, psikiyatrik semptom reaksiyonları, sindirim sistemi reaksiyonları ve yükselmiş serum ürik asit gibi bazı anti-viral ilişkili yan etkiler favipiravir grubunda daha yüksek oranda görülmüştür ${ }^{49}$.

Tayland'da hastanede yatan ancak oksijen tedavisine ihtiyaç duymayan hastalarda yapılan retrospektif gözlemsel bir çalışma sonucunda favipiravir ile tedavinin yedinci gününde klinik iyileşme oranı \%92.6 olarak bulunmuştur $^{50}$.

\section{Umifenovir}

Umifenovir, viral S-proteinleri ve ACE2 reseptörleri arasındaki etkileşimi hedefleyerek viral zarfın membran füzyonunu inhibe eder ve virüsün hücre içine girişini engeller. Rusya ve Çin'de umifenovir, influenza A ve B'nin profilaksisi ve tedavisi için onaylanmış$\operatorname{tir}^{49,51}$.

Çin'de 67 COVID-19 hastalarında yapılan randomize olmayan bir çalışmada, ortalama 9 günlük bir süre boyunca umifenovir ile tedavinin, daha düşük mortalite oranı ve daha yüksek taburcu etme oranı ile ilişkili olduğunu gösterilmiştir ${ }^{52}$. 


\section{D.S. Salmanoğlu, ark.}

1052 hastanın dahil edildiği ve standart bakıma kıyasla çeşitli antiviral ilaçların etkinliğinin değerlendirildiği bir meta analiz çalışmasında umifenovir ile tedavi edilen grup 14. günde daha yüksek negatif RT-PCR oranı ile ilişkilendirilmiştir. Ancak ateş düşmesi, öksürük hafiflemesi ve hastanede kalış süresi açısından anlamlı bir farklılık görülmemiştir ${ }^{53}$.

Umifenovir ve lopinavir-ritonavir veya lopinavirritonavir monoterapisi alan 16, COVID-19 hastasının tek merkezli, geriye dönük bir kohort çalışmasının sonuçları 14 günlük uygulamadan sonra, kontrol grubuna kiyasla umifenovir ile tedavi edilen hastaların \%94'ünde SARS-CoV-2, RT-PCR ile saptanamazken, kontrol grubunda bu oran $\% 53$ bulunmuştur. Umifenovir deney grubu ayrıca göğüs BT'sinde de daha yüksek oranda iyileşme göstermiştir ${ }^{54}$. Şubat 2020'de Changzhou ve Wuhu, Çin'de yürütülen benzer bir retrospektif çalışmada, lopinavir-ritonavir monoterapisi verilen hastalarda \%44.1 viral yük tespitine kıyasla umifenovir alan 16 hastanın tümünde viral yüklerin tespit edilemediği gösterilmiştir. Bu, umifenovirin COVID-19 tedavisinde lopinavir- ritonavirden daha etkili olabileceğini düşündürmektedir ${ }^{55}$.

Umifenovirin yan etkileri arasında bulantı, ishal, yüksek serum aminotransferaz seviyeleri ve baş dönmesi bulunur, ayrica karaciğerde metabolize edildiğinden karaciğer fonksiyon bozukluğu olan hastalarda dikkatli kullanılmalıdır ${ }^{49}$.

\section{Remdesivir}

Remdesivir, viral replikasyon için gerekli bir enzim olan RNA'ya bağımlı RNA polimerazın bir inhibitörü olarak görev yapan geniş spektrumlu bir antiviral ajandır. Ebola tedavisinde kullanılmak için üretilmiştir. Ancak bu virüse karşı etkili değildir ${ }^{56}$. Ebola'yı tedavi etmek için klinik çalışmalarda kullanılan dozlara benzer şekilde, remdesivir, 1. günde $200 \mathrm{mg}$ yükleme dozu olarak uygulanır, ardından dokuz gün boyunca günlük $100 \mathrm{mg}$ IV dozu uygulanır ${ }^{51}$. Remdesivirin SARS-CoV-2 ve ilişkili koronavirüslere karş1 etkinliğ $i$ in vitro çalışmalar ve hayvan modellerinden çıkarılabilir. Yapılan bir çalışmada SARS-CoV-2 enfeksiyonlu bir fare modelinde profilaksi için remdesivir kullanımı akciğerlerdeki viral yükte bir azalmaya ve solunum fonksiyonunda iyileşmeye yol açtığı gösterilmiş$\operatorname{tir}^{57}$.

Ulusal Alerji ve Bulaşıcı Hastalıklar Enstitüsü (NIAID) tarafindan yapılan ilk randomize, plasebo kontrollü klinik çalışmada plasebo grubuna kıyasla remdesivir tedavisi alan 1000 COVID-19 hastasında iyileşme süresi daha kısa bulunmuştur. Ancak, remdesivir alan tedavisi alanlar ile almayanlar arasındaki ölüm oranında önemli bir fark görülmemiştir ${ }^{45}$. Ulusal Sağlık Enstitüsü'nün (NIH) hastanede yatan yetişkin COVID-19 hastalarında gerçekleştirdiği çok uluslu, randomize, çift kör ve plasebo kontrollü yapılan bir çalıșmada, özellikle oksijen desteğine ihtiyaç duyan hastalarda remdesivir tedavisinin iyileşme süresini kısalttığ1 ancak hafif ve orta seviyedeki COVID-19 hastalarında herhangi bir yarar sağlamadığı görülmüştür $^{58}$. Şiddetli COVID-19 sebebiyle hastaneye yatırılan bir hasta kohortunda yapılan başka bir çalışmada, remdesivir ile tedavi edilenlerin \%68'inde klinik iyileşme gözlemlenmiştir ${ }^{59}$. Çelişkili klinik sonuçlara rağmen, FDA, 1 Mayıs 2020'de şiddetli COVID-19 hastalarına hastanede intravenöz remdesivir uygulaması için bir "acil kullanım izni" vermiştir. Çeşitli klinik araştırmalar, remdesivir uygulamasının ardından hepatoksisite gibi ciddi yan etkiler bildirmiştir ${ }^{51}$. İlacın gerçek etkinliği ve faydasının anlaşılabilmesi için farklı yaş gruplarında ve hastalığın farklı evrelerinde daha fazla klinik araştırmaya ihtiyaç vardır. Tüm bunların yanında maliyet ve bulunabilirliği bu ilacın kullanımını sınırlamaktadır ${ }^{1}$.

\section{Lopinavir/ Ritonair}

Lopinavir/ritonavir kombinasyonu, HIV pozitif hastalarda antiretroviral tedavi olarak kullanılmaktadır. Lopinavir, yeni viral oluşum için gerekli bir enzim olan HIV proteazı inhibe etmektedir ${ }^{60}$. Lopinovirin oral biyoyararlanımının düşük olmasından ve CYP3A enziminin substratı olması nedeniyle lopinavir, CYP3A enzim inhibitörü ritonavir ile birlikte uygu-

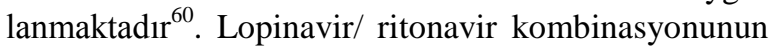
COVID-19 tedavisinde doz rejimi günde iki kez $400 \mathrm{mg} / 100 \mathrm{mg}$ 'd $^{61}{ }^{61}$. in vitro SARS-Cov-2 virüsüne karş1 antiviral etki göstermiştir ancak mevcut veriler, COVID-19 tedavisinde lopinavir/ ritonavirin sinırlı bir rol oynadığını göstermektedir ${ }^{62}$. SARS-CoV 2 enfeksiyonu geçiren 199 hastada yapılan başka bir çalışmada standart bakıma kıyasla lopinovir/ ritonavir tedavisinin klinik iyileşme süresini ve ölüm oranını değiştirmediği görülmüştür. Ancak kör bir çalışma olmaması ve tedaviye gecikmeli başlanması bu çalışmayı sinırlandırmaktadır ${ }^{63}$. Bir meta analizinde lopinavir/ ritonavir ile tedavi gören COVID-19 hastalarında, solunum yetmezliği gelişmesinde, invaziv mekanik ventilasyon ihtiyacında ve ARDS gelişme riskinde hafif bir düşme görülmesine rağmen hastanede kalış süresinde herhangi bir değişiklik görülmemiştir ${ }^{61}$. Lopinavir/ ritonavirin en yaygın yan etkisi ishal ve mide bulanıtsı gibi gastrointestinal rahatsızlıklar (\%28) ve hepatotoksisite (\%2-10)' dir $^{51}$. Lopinavir/ ritonavir tedavisinin gerçek faydalarını kanıtlamak için sürdürülen çalışmalar devam etmektedir.

\section{Ribavirin}

Ribavirin, viral RNA'ya bağımlı RNA polimerazı inhibe eden bir guanin analogudur ${ }^{64}$. Hepatit C, solunum sinsityal virüsü ve Lassa Ateşi gibi bazı viral hemorajik ateşleri tedavi etmek için kullanılan antiviral bir ilaçtır ${ }^{44}$. 2003'te SARS-CoV ve 2012'de MERS-CoV salgınları sırasında kesin bir terapötik fayda sağlamadığından, COVID-19 salgını sırasında 


\section{COVID-19 Tanı Testleri, Tedavisindeki Aşılar ve İlaçlar}

daha az sayıda klinik test yapılmıştır ${ }^{64}$. Hastanede yatan 115 hasta ile yapılan tek merkezli retrospektif bir kohort çalışmasında ribavirin ile tedavi edilen grubun kontrol grubuna kiyasla PCR testinin negatife dönme süresi ve ölüm oranında bir iyileşme görülmemiştir $^{65}$. Hong Kong'da COVID-19 hastalarında çok merkezli, prospektif, açık etiketli, randomize bir faz II çalışması yapılmış olup bu çalışmada kontrol grubundaki hastalar 14 gün boyunca 12 saatte bir lopinavir $400 \mathrm{mg}$ ve ritonavir $100 \mathrm{mg}$ almıştır. Diğer grup 14 gün boyunca her 12 saatte bir lopinavir $400 \mathrm{mg}$, ritonavir $100 \mathrm{mg}, 12$ saatte bir ribavirin $400 \mathrm{mg}$ ve 8 milyon IU doz interferon $\beta$-1b ile tedavi edilmiştir. Elde edilen sonuçlar kombinasyon tedavisinin iyi tolere edildiğini ve hafif ila orta şiddetli COVID-19 hastalarında nazofaringeal sürüntünün negatife dönüş süresini ve hastanede kalış süresini kısalttığını göstermiştir ${ }^{66}$. Ayrıca, SARS-CoV tedavisi için ribavirin klinik çalışmaları, hemolitik anemi, hipokalsemi ve hipomagnezemi ve karaciğer toksisitesi dahil olmak üzere doza bağlı advers ilaç reaksiyonları göstermiştir, aynı zamanda teratojeniktir ve gebelikte kontrendike$\operatorname{dir}^{51}$.

\section{SARS-Cov-2 İçin Klinikte Kullanılan İmmünomo- dülatörler}

\section{Interleukın-1 Inhibitörleri (Anakinra, Canakinumab, Rilonacept)}

Sitokin firtınası, akciğer makrofajlarının hiperaktive olarak IL-1 ve diğer sitokinlerin salındığı bir süreçtir. IL-1 ailesi lökositlerden ve endotel hücrelerinden integrinlerin eksprese edilmesini indükleyerek inflamatuar yanıtları başlatır ve düzenler. En güçlü protinflamatuar sitokinler IL-1 $\alpha$ ve IL-1 $\beta$ 'dır. $\mathrm{Bu}$ açıdan interlökin 1, COVID-19 tedavisinde potansiyel bir hedeftir $^{67}$. IL-1 inhibitörleri arasında anakinra, canakinumab, rilonacept bulunur. Anakinra, romatoid artrit tedavisinde kullanılan rekombinant bir insan IL-1 reseptör antagonistidir ve IL- $1 \alpha$ ve IL-1 $\beta$ 'yi inhibe eder $^{68}$. Anakinra yetişkinlerde SC olarak günde 100 ile $200 \mathrm{mg}$ arasında veya haftada üç kez $100 \mathrm{mg}$ olarak değişen dozlarda uygulanır ${ }^{69}$.

Faz III randomize kontrollü bir çalışmadan elde edilen veriler, anakinra ile IL-1 reseptör blokajının, sepsisli hastaların sağkalımında önemli iyileşme ile ilișkili olduğunu ortaya koymuştur ${ }^{70}$. Orta veya şiddetli COVID-19 pnömonisi olan 9 hastadan oluşan küçük bir vaka serisinde, anakinra kullanımının iyi tolere edildiği ve klinik ve biyolojik belirteçlerin iyileştirilmesinde etkili olduğu bulunmuştur ${ }^{71}$. Standart tedavi grubuna kıyasla yüksek doz anakinra ile tedavi edilen COVID-19 hastalarında yapılan geriye dönük bir çalışmada elde edilen ön kanıtlar, hastalarda solunum fonksiyonlarında iyileşme ve artmış sağ kalım oranı göstermiștir ${ }^{72}$. Yapılan başka bir kohort çalıșmasında anakinranın ağır COVID-19 hastalarında invaziv me- kanik solunum desteği ihtiyacını ve ölüm oranını azalttığ1 gösterilmiştir ${ }^{73}$.

\section{Interleukın-6 Inhibitörleri (Tocilizumab, Sarilumab, Siltuximab)}

Ağır COVID-19 hastalarında diğer proinflamatuar sitokinlerin yanı sıra serumda yüksek IL-6 seviyeleri gözlenir. Yüksek IL-6 seviyesi kötü prognozla ilişkilendirildiğinden bu sitokinlerin inhibe edilmesin ağır COVID-19 hastalarında iyileşmeye sebep olacağ1 düşünülmüştür ${ }^{74}$. Ağır COVID-19 hastalarında kullanılan ve olumlu sonuçlar veren tek IL-6 inhibitörü tocilizumab'tır ${ }^{44}$. Tocilizumab, IL-6 reseptörüne yüksek afinite ile bağlanan bir rekombinant insan IL-6 reseptörü karşıtı monoklonal antikordur. Sitokin salım sendromu (CRS), romatizmal artrit ve sistemik juvenil idiyopatik artrit tedavisi için onaylanmıştır ${ }^{75}$. COVID19'a bağlı gelișen sitokin firtınası için önerilen doz IV $8 \mathrm{mg} / \mathrm{kg}$ (maksimum $800 \mathrm{mg} / \mathrm{doz}$ ) şeklindedir ${ }^{74}$.

Yapılan çalışmalar tocilizumab ile tedavi edilen 21 COVID-19 hastasında yan etki olmaksızın ateş ve IL6 seviyesinde düşme, oksijen tedavisi ve mekanik ventilasyon ihtiyacında azalma ve radyolojik akciğer bulgularında iyileşme ile sonuçlanmıştır. Araştırmacılar, 21 hastadan 20'sinin tamamen iyileştiğini ve tocilizumab tedavisini izleyen iki hafta içinde taburcu edildiğini doğrulamıştır ${ }^{76}$. 544 hasta ile yapılan çok merkezli, retrospektif bir kohort çalışmada, tocilizumab tedavisinin uygulama yolundan bağımsız olarak mekanik ventilasyon ihtiyacını ve ölüm riskini azaltt1ğını gösterilmiştir ${ }^{77}$. Roumier ve ark. 80 yaşından küçük, hastalık süresi 5 günden fazla, şiddetli pnömonisi olan ve hızla kötüleşen 30 hastada (\%23'ü yoğun bakımda tedavi gören) tocilizumab tedavisini incelemişlerdir. Ortalama 8 gün takip edilen hastalarda tocilizumab, mekanik ventilasyon ihtiyacını ve yoğun bakıma yatış riskini azaltmıştır ${ }^{78}$. Mekanik ventilasyona ihtiyaç duyan 100 şiddetli COVID-19 hastasıyla yapılan prospektif bir çalışma sonucunda 10 gün içinde 77 hastada klinik iyileşme veya stabilizasyon görülmüştür ve 15 hasta tamamen iyileşerek taburcu olmuştur. 20 hasta ölmüştür ${ }^{79}$. Yapılan bir metaanalizde standart tedavi gören 2488 hasta ve tocilizumab ile tedavi gören 1153 hasta incelendiğinde tocilizumab grubundaki mortalite oranının (\% 22.4) kontrol grubundan (\% 26.21) daha düşük olduğu gösterilmiş$\operatorname{tir}^{80}$.

Janus Kinase (Jaks) Inhibitörleri (Barisitinib, Ruxolitinib)

Janus Kinazlar (JAK'lar), gerektiğinde konakçı hücrelerde sitokinlerin ve büyüme faktörlerinin yoğunluğunu arttıran transmembran proteinleridir. Janus Kinaz inhibitörleri (JAKi); çoklu, proinflamatuar sitokinlerin eş zamanlı bloke ederek sitokin firtınasını engelleyebilir ve hücresel viral endositozu engelleyerek antiviral etkisiyle diğer immunmodülatörlerden üstünlük göste- 


\section{D.S. Salmanoğlu, ark.}

rebilir $^{81}$. JAK inhibitörleri arasında ruxolitinib, baricitinib, fedratinib, upadacitinib, tofacitinib ve filgotinib bulunur ve bunlar esas olarak miyelofibroz veya romatoid artrit, ülseratif kolit ve psöriazis dahil diğer inflamatuar hastalıkların tedavisinde kullanılır ${ }^{82}$. JAK inhibitörleri, SARS-CoV-2 için nispeten güvenli terapötikler olarak kabul edilmelerine rağmen virüslere karş1 savunmada önemli bir sitokin olan IFN- $\alpha$ 'y1 inhibe etmektedirler ${ }^{83}$. İtalya'da yapılan açık etiketli bir çalışmada lopinavir/ritonavire ek olarak baricitinib ile tedavi edilen 12 hastada kontrol grubuna kiyasla ateş, nefes darlığı ve öksürükte düşüş sağladığı görülmüştür. Bunun yanı sıra solunum fonksiyon testlerinde iyileşme ve daha düşük CRP seviyesi gözlemlenmiştir, hastaların hiçbiri yoğun bakım ünitesine ihtiyaç durmamıştır $^{84}$. Tromboembolizm riski JAKi’lerin kullanımlarını sınırlayan önemli bir durumdur ve kullanılırken bu yan etki göz önünde bulundurulmal1dır. Ancak ruksolitinib bu yan etki riskine sahip değil$\operatorname{dir}^{85}$.

Tümör Nekroz Faktörü (Tnf) İnhibitörleri (Adalimumab, Infliximab, Etanercept)

TNF, bazı otoimmün hastalıklar ve septik şok dahil olmak üzere çeşitli akut ve kronik inflamasyonda rol oynayan önemli bir proinflamatuar sitokindir. TNF- $\alpha$, esas olarak makrofajlar tarafından üretilir, ancak aynı zamanda monositler, B hücreleri ve diğer dokular tarafindan da üretilebilirr ${ }^{86}$. Ateş, apoptoz, kaşeksi ve inflamasyona neden olur ve aynı zamanda tümör oluşumunu ve viral replikasyonu inhibe eder ${ }^{44}$. Birincil işlevi bağışıklık düzenlemesidir ve sepsise IL-1 ve IL6 üreten hücreler aracılığıly yanıt verir ${ }^{68}$. Anti-TNF ajanları (adalimumab, infiximab), romatoid artrit, ankilozan spondilit, inflamatuar bağırsak hastalığı ve psoriatik artritin tedavisinde yaygın olarak kullanılmaktadır ${ }^{69}$. SARS hastalarında serum TNF- $\alpha$ seviyeleri orta derecede yükselirken, COVID-19 enfeksiyonu olan hastalarda hastalığın şiddeti arttıkça artan serum seviyeleri gözlenmiştir ${ }^{81}$. Romatizmal hastalıkları olan ve COVID-19 enfeksiyonu geçirmiş 600 hasta değerlendirildiğinde anti TNF ajanı kullanan hastaların hastaneye yatış oranının daha düşük olduğu görülmüştür $^{87}$. Kuzey Amerikalı enfeksiyon uzmanları tarafından bildirilen 77 hastadan oluşan bir vaka serisi, enfeksiyondan önce anti-TNF tedavisi kullanan 16 hastayı gözlemlemişlerdir. Diğer sitokin bloke edici biyolojikler, JAK inhibitörleri veya diğer immünsupresörler ile tedavi gören 61 hastanın aksine anti-TNF kullanan hiçbir hastanın solunum desteğine ihtiyaç duymadığı veya ölmediği görülmüştür ${ }^{88}$.

\section{Hidroksiklorokin / Klorokin}

Klorokin ve hidroksiklorokin, sistemik lupus eritematozus (SLE) ve romatoid artrit (RA) gibi inflamatuar hastalıkların tedavisi ve ayrıca malaryanın önlenmesi ve tedavisi için kullanılan ilaçlardır ${ }^{51}$. Bu ilaçlar anti inflamatuar etkilerini T ve B hücrelerinin reseptörlerini inhibe ederek gösterir ${ }^{89}$. Bu sayede IL-1 ve IL-6 gibi makrofajlardan sitokin üretimi azalır. Ayrıca TNF- $\alpha$, interferon- $\alpha$ ve $\gamma^{\prime}$ yı inhibe ederler ve SARSCoV-2'ye karşı in vitro antiviral etki göstermişlerdir (90). Bunların tümü, SARS-CoV-2 sitokin firtınasında rol oynayan inflamatuar sitokinlerdir ${ }^{91}$. Doku kültüründe yapılan in vitro deneyler, klorokin ve hidroksiklorokinin endozomal pH'1 artırabildiğini, virüs-hücre füzyonunu önleyebildiğini ve ACE2 reseptörünün glikosilasyonunu ve dolayısıyla SARS-CoV-2 S proteininin ACE2'ye bağlanmasını inhibe edebileceğini göstermiştir $^{92,93}$.

Pandeminin başlangıç döneminde yapılan çalışmalar, COVID-19 hastalarının tedavisinde bu ilaçlarla umut vaat ettiğini göstermiştir. Bu ilaç dünya çapında daha fazla COVID-19 hastasında kullanıldığından, COVID19 tedavisi için etkinliği konusunda çelişkili kanıtlar ortaya çıkmıştır.

28 Mart 2020'de COVID-19 hastalarında klorokin ve hidroksiklorokin kullanımına FDA tarafindan izin verilmiştir. Ancak FDA, ciddi kalp ritmi sorunlarına ilişkin raporlar olduğu için 24 Nisan 2020'de COVID19 için klinik uygulamalar ve hastane ortamı dışında klorokin ve hidroksiklorokin kullanımına ilișkin bir güvenlik uyarısı yayınlamıştır ${ }^{45,93}$. COVID-19 için farmakolojik tedavi alan birçok hastada, QT uzaması, Torsade de Pointes (TdP) ve aritmi dahil olmak üzere ciddi kardiyak yan etkiler gösterilmiştir. Belgelenen ek yan etkiler arasında hepatit, akut pankreatit, nötropeni ve anafilaksi bulunur ${ }^{51}$. Ülkemizde de bu ilaç 7 Mayıs 2021 tarihi itibari ile COVID -19 rehberinden çıkarılmıştır.

Sonuç olarak, SARS-CoV- 2, hızla küresel bir pandemiye yol açan, yaşamları ve geçim kaynaklarını endişe verici bir hızda yok eden oldukça bulaşıcı yeni bir koronavirüstür. $\mathrm{Bu}$ hastalık için dünyanın dört bir yanında birçok ilaç ve aşı adayı araştırılmaktadır. Aşıların ve ilaçların, bu virüsün ortaya çıkardığı küresel halk sağlığı hasarını azaltacağı öngörülmektedir.

\section{Etik Kurul Onay Bilgisi:}

Makale türünün derleme olması sebebi ile etik kurul onayına ihtiyaç yoktur.

Araştırmacı Katkı Beyanı: Fikir ve tasarım: E.Ö.Ç.U., Y.U.; Veri toplama ve işleme: D.S.S., M.S., E.E.Ç.; Analiz ve verilerin yorumlanması: E.Ö.C.U., Y.U.; Makalenin önemli bölümlerinin yazılması: D.S.S., M.S., E.Ö.Ç.U., Y.U.

Destek ve Teşekkür Beyanı: Çalışmamızda herhangi bir finansal destek alınmamıştır.

Çıkar Çatışması Beyanı: Makale yazarının çıkar çatışması beyanı yoktur. 


\section{Kaynaklar}

1. Kahn, J. S., \& McIntosh, K. (2005). History and Recent Advances in Coronavirus Discovery. Pediatric Infectious Disease Journal, 24(11), S223-S227. https://doi.org/10.1097/01. inf.0000188166.17324.60

2. Gouveia, C. C., \& Campos, L. (2020). Coronavirus disease 2019: Clinical review. Acta Medica Portuguesa, 33(13), 45854596. https://doi.org/10.20344/AMP.13957

3. Yang, C. L., Qiu, X., Zeng, Y. K., Jiang, M., Fan, H. R., \& Zhang, Z. M. (2020). Coronavirus disease 2019: A clinical review. In European Review for Medical and Pharmacological Sciences (Vol. 24, Issue 8, pp. 4585-4596). Verduci Editore s.r.l. https://doi.org/10.26355/eurrev_202004_21045

4. Bhatta, M., Nandi, S., Dutta, S., \& Saha, M. K. (2021). Coronavirus (SARS-CoV-2): a systematic review for potential vaccines. In Human Vaccines and Immunotherapeutics (pp. 1-18). Bellwether Publishing, https://doi.org/10.1080/21645515.2020.1865774

5. Du, L., He, Y., Zhou, Y., Liu, S., Zheng, B. J., \& Jiang, S. (2009). The spike protein of SARS-CoV - A target for vaccine and therapeutic development. In Nature Reviews Microbiology (Vol. 7, Issue 3, pp. 226-236). Nature Publishing Group. https://doi.org/10.1038/nrmicro2090

6. Jiang, S., Hillyer, C., \& Du, L. (2020). Neutralizing Antibodies against SARS-CoV-2 and Other Human Coronaviruses. Trends in Immunology, 41(6), 545. https://doi.org/10.1016 j.it.2020.04.008

7. Chan, J. F. W., Kok, K. H., Zhu, Z., Chu, H., To, K. K. W., Yuan, S., \& Yuen, K. Y. (2020). Genomic characterization of the 2019 novel human-pathogenic coronavirus isolated from a patient with atypical pneumonia after visiting Wuhan. Emerging Microbes and Infections, 9(1), 221-236. https://doi.org/10.1080/22221751.2020.1719902

8. Menni, C., Valdes, A. M., Freidin, M. B., Sudre, C. H., Nguyen, L. H., Drew, D. A., Ganesh, S., Varsavsky, T., Cardoso, M. J., El-Sayed Moustafa, J. S., Visconti, A., Hysi, P., Bowyer, R. C. E., Mangino, M., Falchi, M., Wolf, J., Ourselin, S., Chan, A. T., Steves, C. J., \& Spector, T. D. (2020). Real-time tracking of self-reported symptoms to predict potential COVID-19. Nature Medicine, 26(7), 1037-1040. https://doi.org/10.1038/s41591020-0916-2

9. Singh, R., Kang, A., Luo, X., Jeyanathan, M., Gillgrass, A., Afkhami, S., \& Xing, Z. (2021). COVID-19: Current knowledge in clinical features, immunological responses, and vaccine development. The FASEB Journal, 35(3), e21409. https://doi.org/10.1096/fj.202002662R

10. Rodriguez-Morales, A. J., Cardona-Ospina, J. A., GutiérrezOcampo, E., Villamizar-Peña, R., Holguin-Rivera, Y., Escalera-Antezana, J. P., Alvarado-Arnez, L. E., Bonilla-Aldana, D. K., Franco-Paredes, C., Henao-Martinez, A. F., Paniz-Mondolfi, A., Lagos-Grisales, G. J., Ramírez-Vallejo, E., Suárez, J. A., Zambrano, L. I., Villamil-Gómez, W. E., Balbin-Ramon, G. J., Rabaan, A. A., Harapan, H., ... Sah, R. (2020). Clinical, laboratory and imaging features of COVID-19: A systematic review and meta-analysis. In Travel Medicine and Infectious Disease (Vol. 34, p. 101623). Elsevier USA https://doi.org/10.1016/j.tmaid.2020.101623

11. Tian, Y., Rong, L., Nian, W., \& He, Y. (2020). Review article: gastrointestinal features in COVID-19 and the possibility of faecal transmission. Alimentary Pharmacology \& Therapeutics, 51(9), 843-851. https://doi.org/10.1111/apt.15731

12. Chilamakuri, R., \& Agarwal, S. (2021). COVID-19: Characteristics and Therapeutics. Cells, 10(2), 1-29. https://doi.org/10.3390/cells10020206

13. Therapeutic Management | COVID-19 Treatment Guidelines. (n.d.).
14. Search of: SARS-CoV-2 Vaccine | Phase Early Phase 1, 1, 2, 3, 4 - Search Details - ClinicalTrials.gov. (n.d.). Retrieved April 28, 2021, from https://clinicaltrials.gov/ct2/ results/details?cond=SARS-CoV-2+Vaccine\&phase $=01234$

15. Search of: SARS-CoV-2 Vaccine | Phase 3 - Search Details ClinicalTrials.gov. (n.d.). Retrieved April 28, 2021, from https://clinicaltrials.gov/ct2/results/details?cond=SARS-CoV$2+$ Vaccine\&phase $=2$

16. COVID-19 vaccine tracker and landscape. (n.d.).

17. van Riel, D., \& de Wit, E. (2020). Next-generation vaccine platforms for COVID-19. In Nature Materials (Vol. 19, Issue 8, pp. 810-812). Nature Research. https://doi.org/10.1038/s41563020-0746-0

18. COVID-19 vaccines. (n.d.). Retrieved April 28, 2021, from https://www.who.int/emergencies/diseases/novel-coronavirus2019/covid-19-vaccines

19. Kyriakidis, N. C., López-Cortés, A., González, E. V., Grimaldos, A. B., \& Prado, E. O. (2021). SARS-CoV-2 vaccines strategies: a comprehensive review of phase 3 candidates. In $n p j$ Vaccines (Vol. 6, Issue 1, pp. 1-17). Nature Research. https://doi.org/10.1038/s41541-021-00292-w

20. Pfizer-BioNTech COVID-19 Vaccine|FDA. (n.d.). Retrieved April 28, 2021, from https://www.fda.gov/emergencypreparedness-and-response/coronavirus-disease-2019-covid19/pfizer-biontech-covid-19-vaccine

21. Li, Y. Der, Chi, W. Y., Su, J. H., Ferrall, L., Hung, C. F., \& Wu, T. C. (2020). Coronavirus vaccine development: from SARS and MERS to COVID-19. In Journal of Biomedical Science (Vol. 27, Issue 1, p. 104). BioMed Central Ltd. https://doi.org/10.1186/s12929-020-00695-2

22. Polack, F. P., Thomas, S. J., Kitchin, N., Absalon, J., Gurtman, A., Lockhart, S., Perez, J. L., Pérez Marc, G., Moreira, E. D., Zerbini, C., Bailey, R., Swanson, K. A., Roychoudhury, S., Koury, K., Li, P., Kalina, W. V., Cooper, D., Frenck, R. W., Hammitt, L. L., ... Gruber, W. C. (2020). Safety and Efficacy of the BNT162b2 mRNA Covid-19 Vaccine. New England Jo-

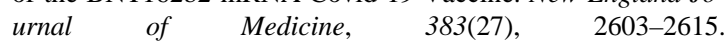
https://doi.org/10.1056/nejmoa2034577

23. FACT SHEET FOR RECIPIENTS AND CAREGIVERS EMERGENCY USE AUTHORIZATION (EUA) OF. (2021). www.janssencovid19vaccine.com.

24. Polack, F., Thomas, S., ... N. K.-... E. J. of, \& 2020, undefined. (n.d.). Safety and efficacy of the BNT162b2 mRNA Covid-19 vaccine. Mass Medical Soc. Retrieved April 28, 2021, from https://www.nejm.org/doi/full/10.1056/NEJMoa2034577

25. Baden, L. R., El Sahly, H. M., Essink, B., Kotloff, K., Frey, S., Novak, R., Diemert, D., Spector, S. A., Rouphael, N., Creech, C. B., McGettigan, J., Khetan, S., Segall, N., Solis, J., Brosz, A., Fierro, C., Schwartz, H., Neuzil, K., Corey, L., ... Zaks, T. (2021). Efficacy and Safety of the mRNA-1273 SARS-CoV-2 Vaccine. New England Journal of Medicine, 384(5), 403-416. https://doi.org/10.1056/NEJMoa2035389

26. Guebre-Xabier, M., Patel, N., Tian, J. H., Zhou, B., Maciejewski, S., Lam, K., Portnoff, A. D., Massare, M. J., Frieman, M. B., Piedra, P. A., Ellingsworth, L., Glenn, G., \& Smith, G. (2020). NVX-CoV2373 vaccine protects cynomolgus macaque upper and lower airways against SARS-CoV-2 challenge. Vaccine, 38(50), 7892-7896. https://doi.org/10.1016/j.vaccine. 2020.10 .064

27. Novavax COVID-19 Vaccine Demonstrates $89.3 \%$ Efficacy in UK Phase 3 Trial | Novavax Inc. - IR Site. (n.d.).

28. Immunity and Safety of Covid-19 Synthetic Minigene Vaccine Full Text View - ClinicalTrials.gov. (n.d.). Retrieved April 28, 2021, from https://clinicaltrials.gov/ct2/show/NCT04276896

29. Tebas, P., Yang, S. P., Boyer, J. D., Reuschel, E. L., Patel, A., Christensen-Quick, A., Andrade, V. M., Morrow, M. P., Kraynyak, K., Agnes, J., Purwar, M., Sylvester, A., Pawlicki, J., Gillespie, E., Maricic, I., Zaidi, F. I., Kim, K. Y., Dia, Y., Frase, 


\section{D.S. Salmanoğlu, ark.}

D., ... Humeau, L. M. (2021). Safety and immunogenicity of INO-4800 DNA vaccine against SARS-CoV-2: A preliminary report of an open-label, Phase 1 clinical trial. EClinicalMedicine, 31. https://doi.org/10.1016/j.eclinm.2020.100689

30. Safety, Immunogenicity, and Efficacy of INO-4800 for COVID19 in Healthy Seronegative Adults at High Risk of SARS-CoV-2 Exposure - Full Text View - ClinicalTrials.gov. (n.d.).

31. Folegatti, P. M., Ewer, K. J., Aley, P. K., Angus, B., Becker, S., Belij-Rammerstorfer, S., Bellamy, D., Bibi, S., Bittaye, M., Clutterbuck, E. A., Dold, C., Faust, S. N., Finn, A., Flaxman, A. L., Hallis, B., Heath, P., Jenkin, D., Lazarus, R., Makinson, R., ... Yau, Y. (2020). Safety and immunogenicity of the ChAdOx1 nCoV-19 vaccine against SARS-CoV-2: a preliminary report of a phase $1 / 2$, single-blind, randomised controlled trial. The Lancet, 396(10249), 467-478. https://doi.org/10.1016/S0140-6736(20)31604-4

32. Ramasamy, M. N., Minassian, A. M., Ewer, K. J., Flaxman, A. L., Folegatti, P. M., Owens, D. R., Voysey, M., Aley, P. K., Angus, B., Babbage, G., Belij-Rammerstorfer, S., Berry, L., Bibi, S., Bittaye, M., Cathie, K., Chappell, H., Charlton, S., Cicconi, P., Clutterbuck, E. A., ... Zizi, D. (2020). Safety and immunogenicity of ChAdOx1 nCoV-19 vaccine administered in a prime-boost regimen in young and old adults (COV002): a single-blind, randomised, controlled, phase 2/3 trial. The Lancet, 396(10267), 1979-1993. https://doi.org/10.1016/S01406736(20)32466-1

33. Janssen COVID-19 Vaccine | FDA. (n.d.). Retrieved April 28, 2021, from https://www.fda.gov/emergency-preparedness-andresponse/coronavirus-disease-2019-covid-19/janssen-covid-19vaccine

34. Soiza, R. L., Scicluna, C., \& Thomson, E. C. (2021). Efficacy and safety of COVID-19 vaccines in older people. In Age and ageing (Vol. 50, Issue 2, pp. 279-283). NLM (Medline). https://doi.org/10.1093/ageing/afaa274

35. Zhang, Y. J., Zeng, G., Pan, H. X., Li, C. G., Kan, B., Hu, Y. L., Mao, H. Y., Xin, Q. Q., Chu, K., Han, W. X., Chen, Z., Tang, R., Yin, W. D., Chen, X., Gong, X. J., Qin, C., Hu, Y. S., Liu, X. Y., Cui, G. L., ... Zhu, F. C. (2020). Immunogenicity and safety of a SARS-CoV-2 inactivated vaccine in healthy adults aged 18-59 years: Report of the randomized, double-blind, and placebo-controlled phase 2 clinical trial. In medRxiv (p. 2020.07.31.20161216) https://doi.org/10.1101/2020.07.31.20161216

36. Zhu, F. C., Li, Y. H., Guan, X. H., Hou, L. H., Wang, W. J., Li, J. X., Wu, S. P., Wang, B. Sen, Wang, Z., Wang, L., Jia, S. Y., Jiang, H. D., Wang, L., Jiang, T., Hu, Y., Gou, J. B., Xu, S. B., Xu, J. J., Wang, X. W., ... Chen, W. (2020). Safety, tolerability, and immunogenicity of a recombinant adenovirus type- 5 vectored COVID-19 vaccine: a dose-escalation, open-label, nonrandomised, first-in-human trial. The Lancet, 395(10240), 1845-1854. https://doi.org/10.1016/S0140-6736(20)31208-3

37. Gam-COVID-Vac - Clarivate. (n.d.). Retrieved April 28, 2021, from https://clarivate.com/drugs-to-watch/drugs-to-watchlisting/gam-covid-vac/

38. Logunov, D. Y., Dolzhikova, I. V., Shcheblyakov, D. V., Tukhvatulin, A. I., Zubkova, O. V., Dzharullaeva, A. S., Kovyrshina, A. V., Lubenets, N. L., Grousova, D. M., Erokhova, A. S., Botikov, A. G., Izhaeva, F. M., Popova, O., Ozharovskaya, T. A., Esmagambetov, I. B., Favorskaya, I. A., Zrelkin, D. I., Voronina, D. V., Shcherbinin, D. N., ... Gintsburg, A L. (2021). Safety and efficacy of an rAd26 and rAd5 vectorbased heterologous prime-boost COVID-19 vaccine: an interim analysis of a randomised controlled phase 3 trial in Russia. The Lancet, 397(10275), 671-681. https://doi.org/10.1016/S01406736(21)00234-8

39. Second interim analysis of clinical trial data showed a $91.4 \%$ efficacy for the Sputnik $V$ vaccine on day 28 after the first dose; vaccine efficacy is over $95 \% 42$ days after the first dose | Official website vaccine against COVID-19 Sputnik V. (n.d.). Retri- eved April 28, 2021, from https://sputnikvaccine.com/ newsroom/pressreleases/second-interim-analysis-of-clinicaltrial-data-showed-a-91-4-efficacy-for-the-sputnik-v-vaccineon-d/

40. Türkiye'de Durum (13.06.2021) | COVID-19 Türkiye Web Portal. (n.d.).

41. Search of: Vaccine | COVID-19 | Turkey | Phase 1, 2, 3 - List Results - ClinicalTrials.gov. (n.d.).

42. TUSEB. (n.d.).

43. Dr. Özlem Ak. (2021). Dr. Özlem Ak [. TÜBİTAK Bilim ve Teknik Dergisi.

44. Onwudiwe, O. A., Weli, H., Shaanu, T. A., Akata, N. M., \& Ebong, I. L. (2020). Pharmacological treatment of COVID-19: an update. Journal of Global Health Reports. https://doi.org/10.29392/001c.17372

45. Lam, S., Lombardi, A., \& Ouanounou, A. (2020). COVID-19: A review of the proposed pharmacological treatments. European Journal of Pharmacology, 886(August), 173451. https://doi.org/10.1016/j.ejphar.2020.173451

46. Joshi, S., Parkar, J., Ansari, A., Vora, A., Talwar, D., Tiwaskar, M., Patil, S., \& Barkate, H. (2021). Role of favipiravir in the treatment of COVID-19. In International Journal of Infectious Diseases (Vol. 102). International Society for Infectious Diseases. https://doi.org/10.1016/j.ijid.2020.10.069

47. Cai, Q., Yang, M., Liu, D., Chen, J., Shu, D., Xia, J., Liao, X., Gu, Y., Cai, Q., Yang, Y., Shen, C., Li, X., Peng, L., Huang, D., Zhang, J., Zhang, S., Wang, F., Liu, J., Chen, L., ... Liu, L. (2020). Experimental Treatment with Favipiravir for COVID19: An Open-Label Control Study. Engineering, 6(10), 11921198. https://doi.org/10.1016/j.eng.2020.03.007

48. Chen, C., Zhang, Y., Huang, J., Yin, P., Cheng, Z., Wu, J., Chen, S., Zhang, Y., Chen, B., Lu, M., Luo, Y., Ju, L., Zhang, J., \& Wang, X. (2020). Favipiravir versus Arbidol for COVID19: A randomized clinical trial. MedRxiv. https://doi.org/10.1101/2020.03.17.20037432

49. Sahebnasagh, A., Avan, R., Saghafi, F., Mojtahedzadeh, M., Sadremomtaz, A., Arasteh, O., Tanzifi, A., Faramarzi, F., Negarandeh, R., Safdari, M., Khataminia, M., Rezai Ghaleno, H., Habtemariam, S., \& Khoshi, A. (2020). Pharmacological treatments of COVID-19. In Pharmacological Reports (Vol. 72, Issue 6). Springer International Publishing. https://doi.org/10.1007/s43440-020-00152-9

50. Rattanaumpawa, Pinyo; Jirajariyavej, Supunnee; Lerdlamyong, K., \& Palavutitotai, Nattawan; Saiyarin, J. (2020). Real-world Experience with Favipiravir for Treatment of COVID-19 in Thailand: Results from a Multicenter Observational Study. All about Your Eyes, 191-192. https://doi.org/10.1515/9780822396086-023

51. Sanders, J. M., Monogue, M. L., Jodlowski, T. Z., \& Cutrell, J. B. (2020). Pharmacologic Treatments for Coronavirus Disease 2019 (COVID-19): A Review. JAMA - Journal of the American Medical Association, 323(18), 1824-1836. https://doi.org/10.1001/jama.2020.6019

52. Wang, Z., Yang, B., Li, Q., Wen, L., \& Zhang, R. (2020). Clinical features of 69 cases with coronavirus disease 2019 in Wuhan, China. Clinical Infectious Diseases, 71(15), 769-777. https://doi.org/10.1093/cid/ciaa272

53. Huang, D., Yu, H., Wang, T., Yang, H., Yao, R., \& Liang, Z. (2021). Efficacy and safety of umifenovir for coronavirus disease 2019 (COVID-19): A systematic review and meta-analysis. Journal of Medical Virology, 93(1), 481-490. https://doi.org/10.1002/jmv.26256

54. Deng, L., Li, C., Zeng, Q., Liu, X., Li, X., Zhang, H., Hong, Z., \& Xia, J. (2020). Arbidol combined with LPV/r versus LPV/r alone against Corona Virus Disease 2019: A retrospective cohort study. Journal of Infection, 81(1), e1-e5. https://doi.org/10.1016/j.jinf.2020.03.002 


\section{COVID-19 Tanı Testleri, Tedavisindeki Aşılar ve İlaçlar}

55. Zhu, Z., Lu, Z., Xu, T., Chen, C., Yang, G., Zha, T., Lu, J., \& Xue, Y. (2020). Arbidol monotherapy is superior to lopinavir/ritonavir in treating COVID-19. Journal of Infection, 81(1), e21-e23. https://doi.org/10.1016/j.jinf.2020.03.060

56. Lin, H. X. J., Cho, S., Meyyur Aravamudan, V., Sanda, H. Y., Palraj, R., Molton, J. S., \& Venkatachalam, I. (2021). Remdesivir in Coronavirus Disease 2019 (COVID-19) treatment: a review of evidence. Infection, 2019(0123456789). https://doi.org/10.1007/s15010-020-01557-7

57. Reza Hashemian, S. M., Farhadi, T., \& Velayati, A. A. (2020) A review on remdesivir: A possible promising agent for the treatment of COVID-19. Drug Design, Development and Therapy, 14, 3215-3222. https://doi.org/10.2147/DDDT.S261154

58. Beigel, J. H., Tomashek, K. M., Dodd, L. E., Mehta, A. K., Zingman, B. S., Kalil, A. C., Hohmann, E., Chu, H. Y., Luetkemeyer, A., Kline, S., Lopez de Castilla, D., Finberg, R. W., Dierberg, K., Tapson, V., Hsieh, L., Patterson, T. F., Paredes, R., Sweeney, D. A., Short, W. R., ... Lane, H. C. (2020). Remdesivir for the Treatment of Covid-19 - Final Report. New England Journal of Medicine, 383(19), 1813-1826. https://doi.org/10.1056/nejmoa2007764

59. Grein, J., Ohmagari, N., Shin, D., Diaz, G., Asperges, E., Castagna, A., Feldt, T., Green, G., Green, M. L., Lescure, F.-X., Nicastri, E., Oda, R., Yo, K., Quiros-Roldan, E., Studemeister, A., Redinski, J., Ahmed, S., Bernett, J., Chelliah, D., ... Flanigan, T. (2020). Compassionate Use of Remdesivir for Patients with Severe Covid-19. New England Journal of Medicine, 382(24), 2327-2336. https://doi.org/10.1056/nejmoa2007016

60. McKee, D. L., Sternberg, A., Stange, U., Laufer, S., \& Naujokat, C. (2020). Candidate drugs against SARS-CoV-2 and COVID-19. In Pharmacological Research (Vol. 157, p. 104859). Academic Press. https://doi.org/10.1016/j. phrs.2020.104859

61. Meini, S., Pagotto, A., Longo, B., Vendramin, I., Pecori, D., \& Tascini, C. (2020). Role of Lopinavir/Ritonavir in the Treatment of Covid-19: A Review of Current Evidence, Guideline Recommendations, and Perspectives. Journal of Clinical Medicine, 9(7), 2050. https://doi.org/10.3390/jcm9072050

62. Choy, K. T., Wong, A. Y. L., Kaewpreedee, P., Sia, S. F., Chen, D., Hui, K. P. Y., Chu, D. K. W., Chan, M. C. W., Cheung, P. P. H., Huang, X., Peiris, M., \& Yen, H. L. (2020). Remdesivir, lopinavir, emetine, and homoharringtonine inhibit SARS-CoV-2 replication in vitro. Antiviral Research, 178, 104786 https://doi.org/10.1016/j.antiviral.2020.104786

63. Cao, B., Wang, Y., Wen, D., Liu, W., Wang, J., Fan, G., Ruan, L., Song, B., Cai, Y., Wei, M., Li, X., Xia, J., Chen, N., Xiang, J., Yu, T., Bai, T., Xie, X., Zhang, L., Li, C., ... Wang, C. (2020). A Trial of Lopinavir-Ritonavir in Adults Hospitalized with Severe Covid-19. New England Journal of Medicine, 382(19), 1787-1799. https://doi.org/10.1056/nejmoa2001282

64. Khalili, J. S., Zhu, H., Mak, N. S. A., Yan, Y., \& Zhu, Y. (2020) Novel coronavirus treatment with ribavirin: Groundwork for an evaluation concerning COVID-19. Journal of Medical Virology, 92(7), 740-746. https://doi.org/10.1002/jmv.25798

65. Tong, S., Su, Y., Yu, Y., Wu, C., Chen, J., Wang, S., \& Jiang, J. (2020). Ribavirin therapy for severe COVID-19: a retrospective cohort study. International Journal of Antimicrobial Agents, 56(3), 1-5. https://doi.org/10.1016/j.ijantimicag.2020.106114

66. Hung, I. F. N., Lung, K. C., Tso, E. Y. K., Liu, R., Chung, T. W. H., Chu, M. Y., Ng, Y. Y., Lo, J., Chan, J., Tam, A. R., Shum, H. P., Chan, V., Wu, A. K. L., Sin, K. M., Leung, W. S., Law, W. L., Lung, D. C., Sin, S., Yeung, P., ... Yuen, K. Y. (2020). Triple combination of interferon beta-1b, lopinavir-ritonavir, and ribavirin in the treatment of patients admitted to hospital with COVID-19: an open-label, randomised, phase 2 trial. The Lancet, 395(10238), 1695-1704. https://doi.org/10.1016/S0140-6736(20)31042-4

67. Dinarello, C. A. (2011). Interleukin-1 in the pathogenesis and treatment of inflammatory diseases. Blood, 117(14), 3720-3732. https://doi.org/10.1182/blood-2010-07-273417
68. Rizk, J. G., Kalantar-Zadeh, K., Mehra, M. R., Lavie, C. J., Rizk, Y., \& Forthal, D. N. (2020). PharmacoImmunomodulatory Therapy in COVID-19. Drugs, 80(13), 1267-1292. https://doi.org/10.1007/s40265-020-01367-z

69. Soy, M., Keser, G., Atagündüz, P., Tabak, F., Atagündüz, I., \& Kayhan, S. (2020). Cytokine storm in COVID-19: pathogenesis and overview of anti-inflammatory agents used in treatment. Clinical Rheumatology, 39(7), 2085-2094. https://doi.org/10.1007/s10067-020-05190-5

70. Shakoory, B., Carcillo, J. A., Chatham, W. W., Amdur, R. L., Zhao, H., Dinarello, C. A., Cron, R. Q., \& Opal, S. M. (2016). Interleukin-1 Receptor Blockade Is Associated With Reduced Mortality in Sepsis Patients With Features of Macrophage Activation Syndrome. Critical Care Medicine, 44(2), 275-281. https://doi.org/10.1097/CCM.0000000000001402

71. Aouba, A., Baldolli, A., Geffray, L., Verdon, R., Bergot, E., Martin-Silva, N., \& Justet, A. (2020). Targeting the inflammatory cascade with anakinra in moderate to severe COVID-19 pneumonia: Case series. In Annals of the Rheumatic Diseases (Vol. 79, Issue 10, pp. 1381-1382). BMJ Publishing Group. https://doi.org/10.1136/annrheumdis-2020-217706

72. Cavalli, G., De Luca, G., Campochiaro, C., Della-Torre, E., Ripa, M., Canetti, D., Oltolini, C., Castiglioni, B., Tassan Din, C., Boffini, N., Tomelleri, A., Farina, N., Ruggeri, A., RovereQuerini, P., Di Lucca, G., Martinenghi, S., Scotti, R., Tresoldi, M., Ciceri, F., ... Dagna, L. (2020). Interleukin-1 blockade with high-dose anakinra in patients with COVID-19, acute respiratory distress syndrome, and hyperinflammation: a retrospective cohort study. The Lancet Rheumatology, 2(6), e325-e331. https://doi.org/10.1016/S2665-9913(20)30127-2

73. Huet, T., Beaussier, H., Voisin, O., Jouveshomme, S., Dauriat, G., Lazareth, I., Sacco, E., Naccache, J. M., Bézie, Y., Laplanche, S., Le Berre, A., Le Pavec, J., Salmeron, S., Emmerich, J., Mourad, J. J., Chatellier, G., \& Hayem, G. (2020). Anakinra for severe forms of COVID-19: a cohort study. The Lancet Rheumatology, 2(7), e393-e400. https://doi.org/10.1016/S26659913(20)30164-8

74. Alijotas-Reig, J., Esteve-Valverde, E., Belizna, C., SelvaO’Callaghan, A., Pardos-Gea, J., Quintana, A., Mekinian, A., Anunciacion-Llunell, A., \& Miró-Mur, F. (2020). Immunomodulatory therapy for the management of severe COVID-19. Beyond the anti-viral therapy: A comprehensive review. Autoimmunity Reviews, 19(7), 102569. https://doi.org/10.1016/j.autrev.2020.102569

75. Wu, R., Wang, L., Kuo, H. C. D., Shannar, A., Peter, R., Chou, P. J., Li, S., Hudlikar, R., Liu, X., Liu, Z., Poiani, G. J., Amorosa, L., Brunetti, L., \& Kong, A. N. (2020). An Update on Current Therapeutic Drugs Treating COVID-19. In Current Pharmacology Reports (Vol. 6, Issue 3, pp. 56-70). Springer. https://doi.org/10.1007/s40495-020-00216-7

76. Xu, X., Han, M., Li, T., Sun, W., Wang, D., Fu, B., Zhou, Y., Zheng, X., Yang, Y., Li, X., Zhang, X., Pan, A., \& Wei, H. (2020). Effective treatment of severe COVID-19 patients with tocilizumab. Proceedings of the National Academy of Sciences of the United States of America, 117(20), 10970-10975. https://doi.org/10.1073/pnas.2005615117

77. Guaraldi, G., Meschiari, M., Cozzi-Lepri, A., Milic, J., Tonelli, R., Menozzi, M., Franceschini, E., Cuomo, G., Orlando, G., Borghi, V., Santoro, A., Di Gaetano, M., Puzzolante, C., Carli, F., Bedini, A., Corradi, L., Fantini, R., Castaniere, I., Tabbì, L., ... Mussini, C. (2020). Tocilizumab in patients with severe COVID-19: a retrospective cohort study. The Lancet Rheumatology, 2(8), e474-e484. https://doi.org/10.1016/S26659913(20)30173-9

78. Jamilloux, Y., Henry, T., Belot, A., Viel, S., Fauter, M., El Jammal, T., Walzer, T., François, B., \& Sève, P. (2020). Should we stimulate or suppress immune responses in COVID-19? Cytokine and anti-cytokine interventions. Autoimmunity Reviews, 19(7), 102567. https://doi.org/10.1016/j.autrev.2020.102567 


\section{D.S. Salmanoğlu, ark.}

79. Nasonov, E., \& Samsonov, M. (2020). The role of Interleukin 6 inhibitors in therapy of severe COVID-19. Biomedicine and Pharmacotherapy, 131 110698. https://doi.org/10.1016/j.biopha.2020.110698

80. Boregowda, U., Perisetti, A., Nanjappa, A., Sridharan, G. K. Gajendran, M., \& Goyal, H. (2020). Addition of tocilizumab to the standard of care reduces mortality in severe COVID-19: A systematic review and meta-analysis. In medRxiv. https://doi.org/10.1101/2020.07.10.20150680

81. Stebbing, J., Phelan, A., Griffin, I., Tucker, C., Oechsle, O., Smith, D., \& Richardson, P. (2020). COVID-19: combining antiviral and anti-inflammatory treatments. In The Lancet Infectious Diseases (Vol. 20, Issue 4, pp. 400-402). Lancet Publishing Group. https://doi.org/10.1016/S1473-3099(20)30132-8

82. Owji, H., Negahdaripour, M., \& Hajighahramani, N. (2020) Immunotherapeutic approaches to curtail COVID-19. International Immunopharmacology, 88(July), 106924 https://doi.org/10.1016/j.intimp.2020.106924

83. Elli, E. M., Baratè, C., Mendicino, F., Palandri, F., \& Palumbo, G. A. (2019). Mechanisms Underlying the Anti-inflammatory and Immunosuppressive Activity of Ruxolitinib. Frontiers in Oncology, 9, 1186. https://doi.org/10.3389/fonc.2019.01186

84. Cantini, F., Niccoli, L., Matarrese, D., Nicastri, E., Stobbione, P., \& Goletti, D. (2020). Baricitinib therapy in COVID-19: A pilot study on safety and clinical impact. In Journal of Infection (Vol. 81, Issue 2, pp. 318-356). W.B. Saunders Ltd. https://doi.org/10.1016/j.jinf.2020.04.017

85. FDA issues tofacitinib safety alert rheumatology.medicinematters.com. (n.d.). Retrieved April 27, 2021, from https://rheumatology.medicinematters.com/rheumatoidarthritis-/tofacitinib/fda-issues-tofacitinib-safety-alert/16527134

86. NIH clinical trial testing antiviral remdesivir plus antiinflammatory drug baricitinib for COVID-19 begins | National Institutes of Health (NIH). (n.d.). Retrieved April 27, 2021, from https://www.nih.gov/news-events/news-releases/nihclinical-trial-testing-antiviral-remdesivir-plus-antiinflammatory-drug-baricitinib-covid-19-begins

87. Gianfrancesco, M., Hyrich, K. L., Hyrich, K. L., Al-Adely, S., Al-Adely, S., Carmona, L., Danila, M. I., Gossec, L., Gossec, L., Izadi, Z., Jacobsohn, L., Katz, P., Lawson-Tovey, S., Lawson-Tovey, S., Mateus, E. F., Rush, S., Schmajuk, G., Simard, J., Strangfeld, A., ... Robinson, P. C. (2020). Characte- ristics associated with hospitalisation for COVID-19 in people with rheumatic disease: Data from the COVID-19 Global Rheumatology Alliance physician-reported registry. Annals of the Rheumatic Diseases, 79(7), 859-866. https://doi.org/10.1136/annrheumdis-2020-217871

88. Winthrop, K. L., Brunton, A. E., Beekmann, S., Polgreen, P., Baddley, J., Saag, K. G., Calabrese, C., Calabrese, L., Robinson, P. C., Wallace, Z. S., \& Curtis, J. R. (2021). SARS CoV-2 infection among patients using immunomodulatory therapies. In Annals of the Rheumatic Diseases (Vol. 80, Issue 2, pp. 269271). BMJ Publishing Group. https://doi.org/10.1136/ annrheumdis-2020-218580

89. Sperber, K., Quraishi, H., Kalb, T. H., Panja, A., Stecher, V., \& Mayer, L. (1993). Selective regulation of cytokine secretion by hydroxychloroquine: Inhibition of interleukin 1 alpha (IL-1- $\alpha$ ) and IL-6 in human monocytes and T cells. Journal of Rheumatology, 20(5), 803-808. https://pubmed.ncbi.nlm.nih.gov/ 8336306/

90. Yao, X., Ye, F., Zhang, M., Cui, C., Huang, B., Niu, P., Liu, X., Zhao, L., Dong, E., Song, C., Zhan, S., Lu, R., Li, H., Tan, W., \& Liu, D. (2020). In Vitro Antiviral Activity and Projection of Optimized Dosing Design of Hydroxychloroquine for the Treatment of Severe Acute Respiratory Syndrome Coronavirus 2 (SARS-CoV-2). Clinical Infectious Diseases, 71(15), 732-739. https://doi.org/10.1093/cid/ciaa237

91. Das, S., Bhowmick, S., Tiwari, S., \& Sen, S. (2020). An Updated Systematic Review of the Therapeutic Role of Hydroxychloroquine in Coronavirus Disease-19 (COVID-19). Clinical Drug Investigation, 40(7), 591-601. https://doi.org/10.1007 /s40261-020-00927-1

92. Guzik, T. J., Mohiddin, S. A., Dimarco, A., Patel, V., Savvatis, K., Marelli-Berg, F. M., Madhur, M. S., Tomaszewski, M., Maffia, P., D’Acquisto, F., Nicklin, S. A., Marian, A. J., Nosalski, R., Murray, E. C., Guzik, B., Berry, C., Touyz, R. M., Kreutz, R., Dao, W. W., ... McInnes, I. B. (2020). COVID-19 and the cardiovascular system: Implications for risk assessment, diagnosis, and treatment options. In Cardiovascular Research (Vol. 116, Issue 10, pp. 1666-1687). Oxford University Press. https://doi.org/10.1093/cvr/cvaa106

93. Li, X., Wang, Y., Agostinis, P., Rabson, A., Melino, G., Carafoli, E., Shi, Y., \& Sun, E. (2020). Is hydroxychloroquine beneficial for COVID-19 patients? Cell Death and Disease, 11(7). https://doi.org/10.1038/s41419-020-2721-8 